\title{
19. THE EFFECTS OF DIAGENESIS ON THE MICROSTRUCTURE OF EOCENE SEDIMENTS BORDERING THE BALTIMORE CANYON TROUGH ${ }^{1}$
}

\author{
Roy H. Wilkens, Massachusetts Institute of Technology \\ B. Charlotte Schreiber, Queens College (C.U.N.Y.) and Lamont-Doherty Geological Observatory \\ of Columbia University \\ and \\ Louis Caruso and Gene Simmons, Massachusetts Institute of Technology²
}

\begin{abstract}
Sediments at two sites bordering the Baltimore Canyon Trough of the eastern North American continental shelf were cored and logged during Leg 95 of the Deep Sea Drilling Project (DSDP). Results of shipboard measurements of carbonate content, as well as examination of sediment samples using a scanning electron microscope, show that at both sites there is an isochemical change in sediment properties resulting from diagenesis of biogenic silica and calcium carbonate.

The ooze to chalk transition appears to be a gradual change in the sediment resulting from ever increasing dissolution and reprecipitation of calcium carbonate. A major change in sediment properties that may be equated to the widespread seismic reflector $A^{c}$ occurs at the depth where biogenic silica (opal-A) dissolves and reprecipitates as opaline lepispheres (opal-CT). Unlike the gradual nature of the change in the carbonate, the silica reaction begins and goes to completion in a matter of a few meters. The dissolution of opal-A, and its reprecipitation as opal-CT, reduces sediment porosity by about $20 \%$, as well as continuing to increase compressional-wave velocity. This abrupt change in acoustic impedance of the sediments is responsible at this location for seismic reflector $\mathrm{A}^{\mathrm{c}}$.

Cross-correlations of $\log$ measurements of velocity and formation factor (electrical resistivity) are used to separate different lithologic and diagenetic units and subunits at both sites. Large scale sediment units identified by examination of logging data correspond to lithologic units identified by shipboard stratigraphers. Well-log measurements, however, identify more detailed variations in sediment properties.
\end{abstract}

\section{INTRODUCTION}

One of the least understood realms of the earth's surface is the upper few hundred meters of sediments that cover the ocean bottom. It is in this zone that the transformation of the sediments from collections of individual grains to solid sedimentary rock takes place. We have some understanding of the behavior of the endpoints of this process through the use of simplified mixture theories for oozes (Berryman, 1981; Ogushwitz, 1985) and continuum mechanics for rocks (Kuster and Toksöz, 1974, Toksöz et al., 1976). Both constructs depend on the same two variables; structure and composition. Structure, in the case of ooze, means the presence of non-interactive (not cemented) grains in a fluid medium. For rocks, structure can be thought of as not only the presence of a rigid framework of crystalline material, but also the geometry of that material-the shapes and distributions of both pores and grains. In the near-surface sediments, the process of compaction and lithification becomes a third variable. While compaction alters the geometry of the grains in the sediment, cementation changes the grain to grain relationship from that of independent particles

\footnotetext{
${ }^{1}$ Poag, C. W., Watts, A. B., et al., Init. Repts. DSDP, 95: Washington (U.S. Govt. Printing Office).

2 Addresses: (Wilkens, Caruso, Simmons) Department of Earth, Atmospheric, and Planetary Sciences, Massachusetts Institute of Technology, Cambridge, MA 02139; (Schreiber) Department of Earth and Environmental Sciences, Queens College (C.U.N.Y.), Flushing, NY 11367 and Lamont-Doherty Geological Observatory of Columbia University, Palisades, NY 10964.
}

to that of a welded framework. Observation of these changes and their relationship to changes in physical properties will help to define further the response of the sedimentary column to lithification.

The geophysical well-logging program carried out at Sites 612 and 613 of DSDP Leg 95 offered, in some sense, the best of both the laboratory and field experiment worlds. In situ measurements of both compressional-wave velocity and electrical resistivity were made many thousands of times throughout the length of the boreholes. In addition, the almost continuous core recovery allowed for close examination of the sediment structure. The purpose of this study is to examine the microstructure of sediment samples from these two sites and to relate changes in these structures to changes in velocity and resistivity measured downhole. The velocity and resistivity logs were chosen for two reasons: (1) They are primary measurements; neither log depends on a response calibrated to limestone or sandstone. (2) Both measurements respond to the structure of the sediments in the geometrical sense, while cementation increases velocity through stiffening of the sediment framework. Changes in the compressional-wave velocity and bulk density of the sediments are related to seismic reflectors that can be seen in regional seismostratigraphy (Goldberg et al., this volume).

\section{TECHNIQUES}

Values of compressional-wave velocity $\left(V_{\mathrm{p}}\right)$ were measured in situ using the Schlumberger long-spaced sonic sonde (SLS-TA). The sonde generates an acoustic signal that triggers first one, then another receiv- 
er along the axis of the borehole. Formation velocity is calculated by dividing the spacing between the two receivers $(0.61 \mathrm{~m})$ by the delay time measured between the successive triggering of those receivers. Formation resistivities were measured using the dual induction-latero$\log$ (DIL). The DIL records both intermediate and deep formation properties which, in a permeable medium, will differ somewhat because of the replacement of pore fluid by drilling mud near the borehole (invasion). Typical values of permeability of unconsolidated marine sediments, however, are quite low, between 1 millidarcy and $1 \mathrm{mi}$ crodarcy (Bryant et al., 1975). Values from both Sites 612 and 613 indicate that there is very little invasion of the sediment, as both intermediate and deep logs record virtually identical values. The values we have used in the following analysis are the deep resistivities. Natural gamma ray logs (GR) are also included as a qualitative index of clay content in the sediments. The gamma ray log records the natural radiation of a formation. The amount of radioactive material in the biogenic component of oceanic sediments is relatively low. Our observations suggest that volcanic ash and detrital clays generally contain the bulk of radioactive elements in this environment. Increases in $\mathrm{Al}_{2} \mathrm{O}_{3}$ content seen in chemical analyses (Thein and von Rad, this volume) correspond with increased gamma counts (GAPI-American Petroleum Institute gamma units), supporting this assumption.

The data returned by the downhole tools have been smoothed using a running average with a $1.0-\mathrm{m}$ window, values being calculated at $0.5-\mathrm{m}$ intervals. This procedure has been followed to reduce the number of data points to a more manageable number for analysis. Original $\log$ data are reported at 0.15 -m intervals, even though the tools average over intervals on the order of $1.0 \mathrm{~m}$ or so. In addition, smoothing may help when comparing log values to values of the same parameters measured aboard ship on the recovered core. Particularly in areas where there is variability on a very close spatial scale, the use of average values reduces the possibility of a large disagreement between log and laboratory values resulting from a small offset in depths between the logs and the recovered core. Comparisons of laboratory and $\log$ values of velocity, bulk density, and porosity are presented in Goldberg et al. (this volume).

Samples from the core selected for scanning electron microscope (SEM) observation were wrapped in wet paper and refrigerated immediately after sampling. Critical point drying, a technique developed in the biological sciences for preservation of delicate tissue (Spurr, 1969; Jim, 1985), was used to preserve the delicate sediment texture. Critical point drying is a two-step process involving (1) the exchange of pore fluid for acetone over a period lasting several weeks and (2) combination of the acetone with liquid carbon dioxide in a pressure vessel at a temperature and pressure that make the two fluids miscible. The acetone/carbon dioxide mixture is then slowly bled from the sample in the form of a gas. Slow bleeding preserves delicate textures in the sediments. A final step in the preparation process is the impregnation of the samples with ultra low viscosity epoxy. Impregnated samples were then polished using a final grit size of $0.1 \mu \mathrm{m}$. In some cases samples delaminated, or separated along bedding planes, during the initial exchange process. However, the structure of the sediment within the laminae themselves appears to be reasonably intact. Samples, taken adjacent to the SEM samples, were used in the determination of density and porosity by gravimetric methods and carbonate content using an acid bomb (Boyce, 1976).

\section{DATA}

The stratigraphic columns at Sites 612 and 613 are similar in both their composition and in their physical properties (Site 612 and 613 chapters, this volume). Each consists of an upper section of Pleistocene to upper Miocene terrigenous muds and glauconitic sands (Unit I) overlying unconformably lower Oligocene to uppermost lower Eocene siliceous nannofossil oozes and chalks (Unit II). Below this is a lower Miocene section of porcellanitic nannofossil chalk (Unit III), which is chemically similar to Unit II (Thein and von Rad, this volume), but has undergone extensive diagenetic changes. At both sites the Unit II/Unit III boundary corresponds to the dissolution of biogenic silica (opal-A) and the precipitation of opal-CT (porcellanite), a precursor to quartz in the diagenetic sequence of biogenic silica in ocean sediments (Ernst and Calvert, 1969; Wise and Weaver, 1974; Reich and von Rad, 1979). Hole 613 bottomed in lower Eocene sediments, but coring at Site 612 extended into two marly mudstone and chalk units (Unit IV: lower to middle. Maestrichtian, Unit V: Campanian) beneath an unconformity at the base of Unit III. The depth ranges of the units at Site 612 are shown in Figure 1, along with shipboard measurements of density, porosity, and carbonate content plotted versus depth.

This study is concerned primarily with the change in sediment structure between oozes and the more consolidated chalks and porcellanitic chalks at both sites. Slight volumetric changes in sediment composition which may have triggered the structural changes are discussed briefly later, and at greater length, in Thein and von Rad (this volume). These relatively small differences in composition would not have a significant effect on sediment properties were it not for the coeval diagenetic event. Laboratory determinations of the grain densities of samples taken at these sites suggest a relatively uniform distribution among biogenic carbonate and silica in Units II and III. Grain densities for Units II and III at Site 612 are 2.44 and $2.47 \mathrm{~g} / \mathrm{cm}^{3}$ respectively. At Site 613 these values are 2.51 and 2.43 for the same units (Goldberg et al., this volume). This small difference in grain densities reflects the fact that there is very little change in the carbonate content of the sediments across the Unit II/Unit III boundary at either site (Fig. 1). It is reasonable to assume that the differences in the properties of these units results from a change in structure that the sediments have undergone during lithification. SEM observation of the sedimentary components supports this assumption.

A further modification of the data is necessary before a comparison of log measurements from Sites 612 and 613 can be considered. Site 612 pore waters exhibit a strong salinity gradient, from $34 \mathrm{ppt}$ near the surface to over $50 \mathrm{ppt}$ at the bottom of the hole. At Site 613 there is no gradient, as values remain near $34 \mathrm{ppt}$ throughout the section. In order to compare the electrical measurements at the two sites, it is necessary to normalize the resistivity values using the resistivity of the pore fluid. The ratio of the resistivity of the formation to the resistivity of the pore fluid in that formation is known as the formation factor:

$$
F=\frac{R_{0}}{R_{\mathrm{w}}},
$$

where $F$ is the formation factor, $R_{0}$ is the formation resistivity, and $R_{\mathrm{w}}$ is the pore fluid resistivity. $F$ has been found to be nearly constant for individual rocks over a wide range of pore-fluid resistivities. It has long been used in the oil industry to estimate pore-fluid resistivity, by comparing the formation resistivity measured away from the borehole to the value of $F$ in the invaded zone, where drilling fluid of known resistivity has replaced pore fluid in the rocks (Ward and Fraser, 1967; Serra, 1984; Timur and Toksöz, 1985; Hearst and Nelson, 1985). At 


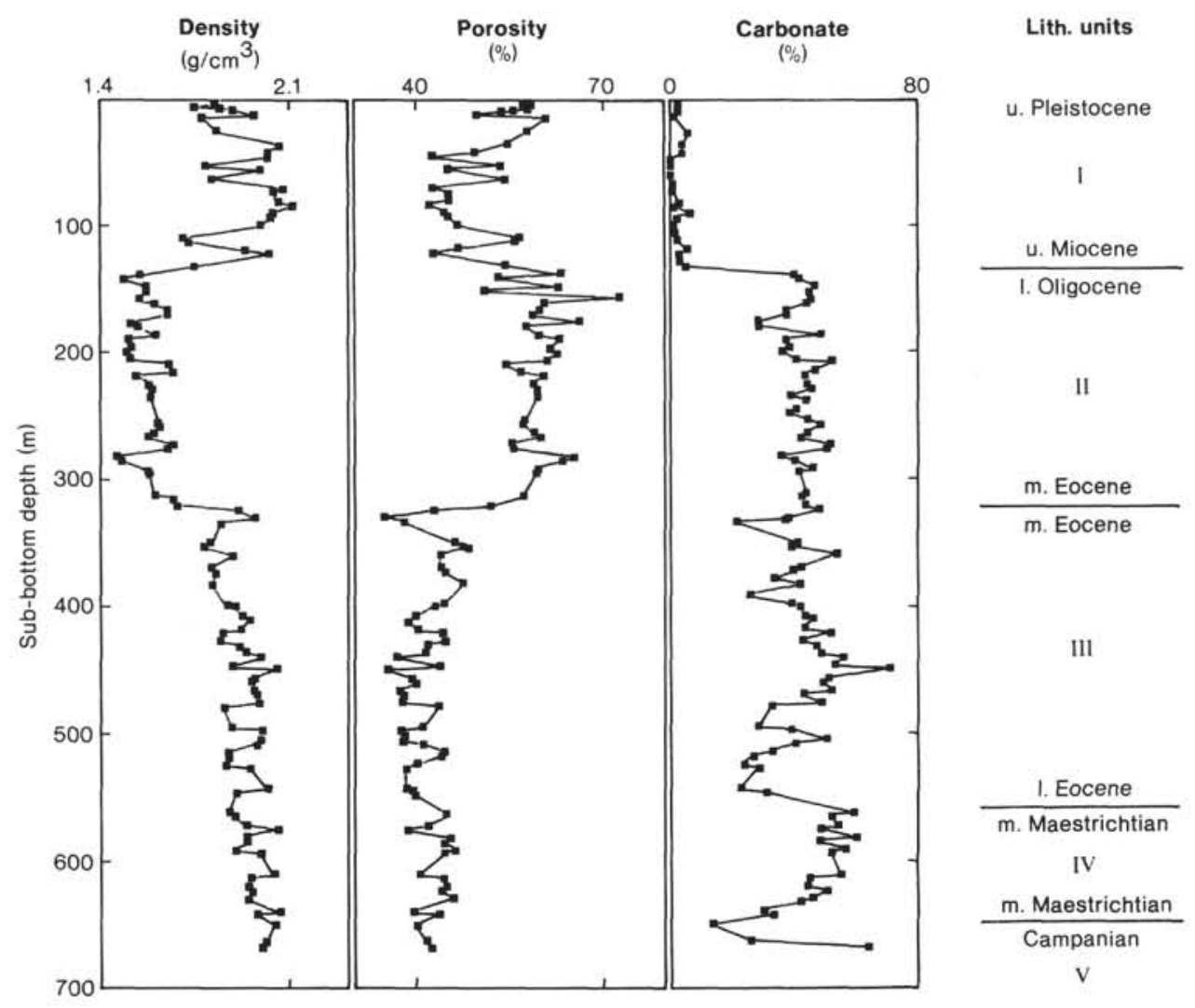

Figure 1. Shipboard measurements of density, porosity, and carbonate content plotted versus depth in core at Site 612. Lithologic units are from site stratigraphy (see Site 612 chapter, this volume).

Sites 612 and 613 there was very little invasion, but pore fluid samples were taken at regular intervals, and pore fluid resistivity was calculated from the measured salinity and geothermal gradient.

\section{Logs}

\section{Site 612}

Site 612 was drilled near U.S.G.S. seismic Line 25, in $1404 \mathrm{~m}$ of water. A plot of $V_{\mathrm{p}}, F$, and GR versus depth at Site 612 is presented in Figure 2. At both sites the drill pipe was left in the hole to a depth of approximately $100 \mathrm{~m}$ sub-bottom to prevent collapse of the hole in the upper, most unconsolidated sediments. At Site 612, Unit I was only $136 \mathrm{~m}$ thick and consequently was only logged over its lowermost few meters. A similarity in the trends of both $V_{\mathrm{p}}$ and $F$ in Units II and III can be seen. Relative maxima and minima within each section appear to be correlated. In Unit III both $V_{\mathrm{p}}$ and $F$ exhibit a general increase with depth. In Unit II velocity slowly increases with depth, while the formation factor is somewhat more constant. Gamma ray data indicate an increase in radioactive components which our observations and x-ray diffraction (XRD) analyses (Thein and von Rad, this volume) suggest is caused by increasing clay content. However, the gamma ray data show only a weak correlation with either $V_{\mathrm{p}}$ or $F$, and in absolute terms indicate a very low abundance of radioactive material.

There is a strong correlation between $V_{\mathrm{p}}$ and $F$; illustrated in a crossplot of the two properties (Fig. 3). In ad- dition, the lithologic units occupy essentially exclusive fields on the plot. Only the data for the siliceous carbonate Units II and III are presented in Figure $4 . V_{\mathrm{p}}$ in Unit II, with the exception of a few points, does not exceed $1.85 \mathrm{~km} / \mathrm{s}$, whereas the same parameter in Unit III is almost never less than $1.85 \mathrm{~km} / \mathrm{s}$. Sections of both units have values of $F$ in the range of 4.0 to 5.0 , but $V_{\mathrm{p}}$ is greater in Unit III for a given value of $F$ than in Unit II. This is the result of increased cementation with depth. Given the relatively low abundance of clay in the sediments, the formation factor is primarily a function of porosity, because it is the pore fluid that is the conducting medium. As the volume of seawater is reduced by porosity reduction (compaction), resistivity (and thus $F$ ) increases. Acoustic wave propagation, however, is controlled not only by the relative abundance of pore fluid and solid particles, but also by the extent to which the sediment grains have been welded into a solid framework (cementation). Thus, an ooze and a chalk with similar porosities will not have the same velocities, because of the increased bulk and shear moduli of the chalk framework.

A closer examination of the Unit II data, which encompasses the ooze-to-chalk transition, reveals even finer detail in the $V_{\mathrm{p}} / F$ relationship. Once again the depth plots exhibit similarity in trends (Fig. 5), but the crossplot contains much more detailed information (Fig. 6). Most of the data fall within the velocity range of 1.6 to $1.85 \mathrm{~km} / \mathrm{s}$ and the $F$ range 2.5 to 4.5 . Within these ranges, however, there appear to be distinct, parallel trends 


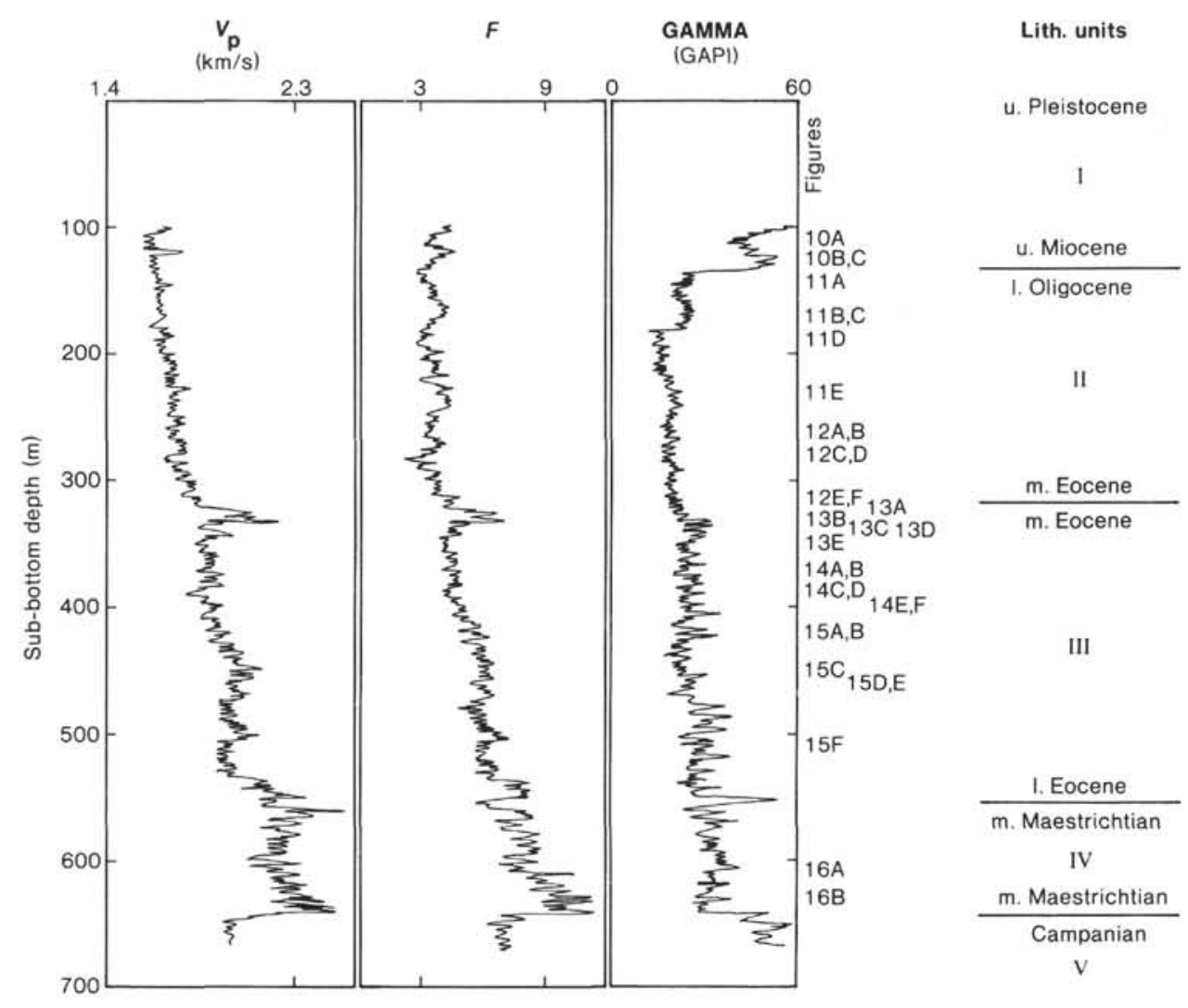

Figure 2. Well-log data for compressional-wave velocity $\left(V_{\mathrm{p}}\right)$, formation factor $(F)$, and gamma ray counts (GAMMA) at Site 612, plotted versus sub-bottom depth. Numbers to the right of gamma ray log refer to figures showing samples taken at indicated levels in the core.

of $V_{\mathrm{p}}-F$ that correspond to discrete stratigraphic intervals (Subunits IIA, IIB, IIC, IID). Each of these groupings appears to define a velocity/formation factor relationship that is controlled by the differences in porosity within the subunit. The trends are offset by different velocities for a given formation factor for each group.

\section{Site 613}

Site 613 was drilled $30 \mathrm{~km}$ downslope from Site 612 , in a water depth of $2323 \mathrm{~m}$, approximately $900 \mathrm{~m}$ deeper than the water at Site 612. Plots of $V_{\mathrm{p}}, F$, and GR versus depth for this site are presented in Figure 7 and SEM sample levels have been identified by figure numbers. The sediments of Site 613 were divided into three units, corresponding to the upper three units sampled at Site 612 . Unit I at Site 613 was only spot cored. The cores contained large volumes of hydrogen sulfide gas which disturbed the sediment structure even as the cores were split. Furthermore, the caliper log indicated that the hole diameter was severely under gauge (i.e., narrowed) in most of Unit I, making the log measurements in the unit suspect. Because of these problems the following discussion is focused on the structures of Units II and III at Site 613 in comparison to the observations already made for the same units at Site 612 .

A crossplot of $V_{\mathrm{p}}$ and $F$ of Units II and III for Site 613 (Fig. 8) falls neatly within the range of the data collected at Site 612 . The Site 612 data, however, cover a wider range of values of both parameters. At the lower end of the plot, the sediment column at Site 613 did not contain the oozes that appeared at Site 612 . Thus, the velocities and formation factors at the top of Unit II at Site 613 are somewhat greater than those at the top of Unit II at Site 612. However, the field of the Site 613 Unit II chalks is almost identical to the Unit II chalks at Site 612 (Fig. 6). The higher values of $V_{\mathrm{p}}$ and $F$ that are seen at Site 612, but not at Site 613, are probably the result of the failure at Site 613 to penetrate the bottom of Unit III. Almost all of the velocities greater than 2.1 $\mathrm{km} / \mathrm{s}$ at Site 612 occurred within $20 \mathrm{~m}$ of the Unit III/ Unit IV boundary.

\section{Microstructure}

\section{Site 612}

Views of the relatively unconsolidated muds that comprise Unit $I$ at both Sites 612 and 613 are shown in Figures 9 and 10 . These sediments are almost totally derived from terrigenous sources. The sand-sized grains are generally glauconite or quartz, with the quartz grains commonly exhibiting embayed and irregular margins caused by partial dissolution. Clay and fine-grained quartz predominate in the matrix, with coccoliths and other biogenic fragments becoming slightly more abundant with depth. In terms of both $V_{\mathrm{p}}$ and $F$, these sediments are not very different from the underlying biogenic oozes of Unit II, although Unit I sediments have greater bulkdensity values than Unit II sediments (Fig. 1) because of 


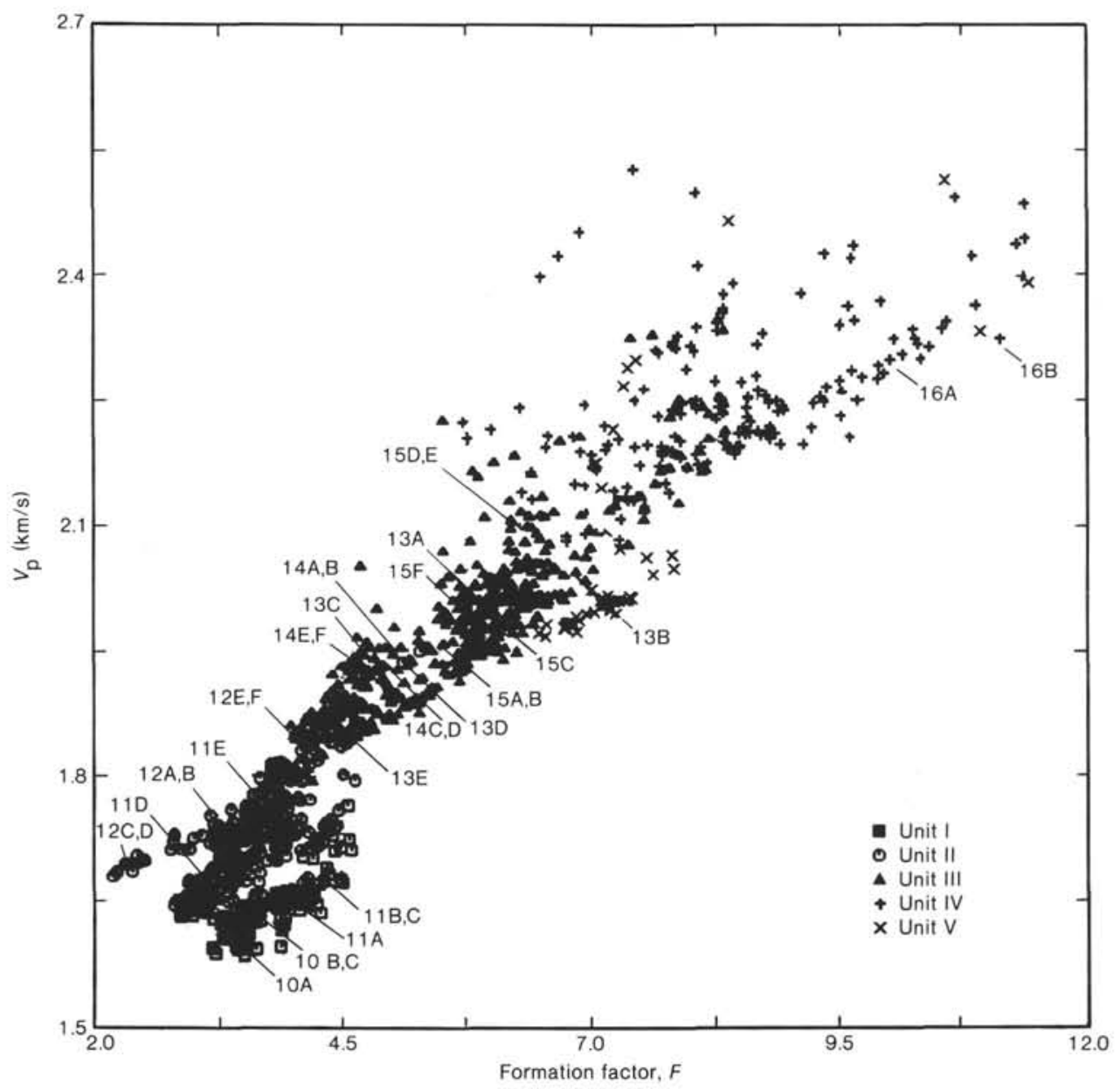

Figure 3. Crossplot of $V_{\mathrm{p}}$ and $F$ from Figure 2. Numbers refer to figures showing samples.

the larger grain densities of Unit I (approximately 2.65 $\mathrm{g} / \mathrm{cm}^{3}$ for Unit I versus $2.44 \mathrm{~g} / \mathrm{cm}^{3}$ for Unit II, Goldberg et al., this volume). Much higher GR values in Unit I (Fig. 2) indicate, as do the SEM observations, that terrigenous clays are much more abundant in Unit I than in Units II or III.

There is a marked increase in the abundance of large microfossil tests in the oozes of Unit II (Fig. 11) as compared to the terrigenous muds of Unit I (Figs. 9, 10). The carbonate content of the sediments increases from values generally less than $10 \%$ in Unit I to near $50 \%$ in Unit II (Fig. 1). Coccolith platelets in Units II and III contribute a significant fraction of the matrix. The large tests, both calcareous (foraminifers) and siliceous (radiolarians and diatoms) appear to be mostly unfilled by matrix material. The presence of large, empty tests can maintain relatively high porosities in marine sediments (Schreiber, 1968; Mayer, 1979; Bachman, 1984; Wilkens and Handyside, 1985) and explain why a porosity of around $50-60 \%$ is seen throughout Unit II. Corrosion of the larger tests in the ooze samples appears to be quite variable. In some samples the radiolaria are somewhat etched, in others the foraminifers are degraded, and yet other samples exhibit no serious dissolution of any of the component tests.

There does not appear to be any apparent reason why the values of $F$ in Subunit IIB are different from those of Subunits IIA and IIC. Samples of Subunit IIB tended to delaminate (separate along planes) during sample preparation more than those of Subunit IIC; however, the single sample from Subunit IIA also fell apart during preparation. The amount of clay in Subunits IIA and IIB, as indicated by the gamma ray log (Fig. 5), is relatively greater than in Subunit IIC. This may account for the generally higher value of $F$ in Subunit IIA compared to IIC, as fine grained particles tend to block conductive paths in the sediment. Grain size may also account for the Subunit IIB values of $F$ being generally high for their velocity. In a very qualitative sense it does appear that the samples from Subunit IIB contain relatively fewer intact tests, and thus a finer grain size. Another possibility is that the sediments of Subunit IIA have already undergone some very slight, unobserved, cementation, owing perhaps to some difference in the composition of the different subunits. Schlanger and Douglas (1974) have suggested that sediments have a "diagenetic potential" that is governed by their initial composition. Given adjacent strata in a sediment column without steep environmental gradients (temperature, pore water chemistry, etc.), shallower sediments may begin cementation earlier than sediments they overly if they have a greater diagenetic potential.

The chalks of Unit II are represented by Subunit IID, and views of three representative samples are presented 


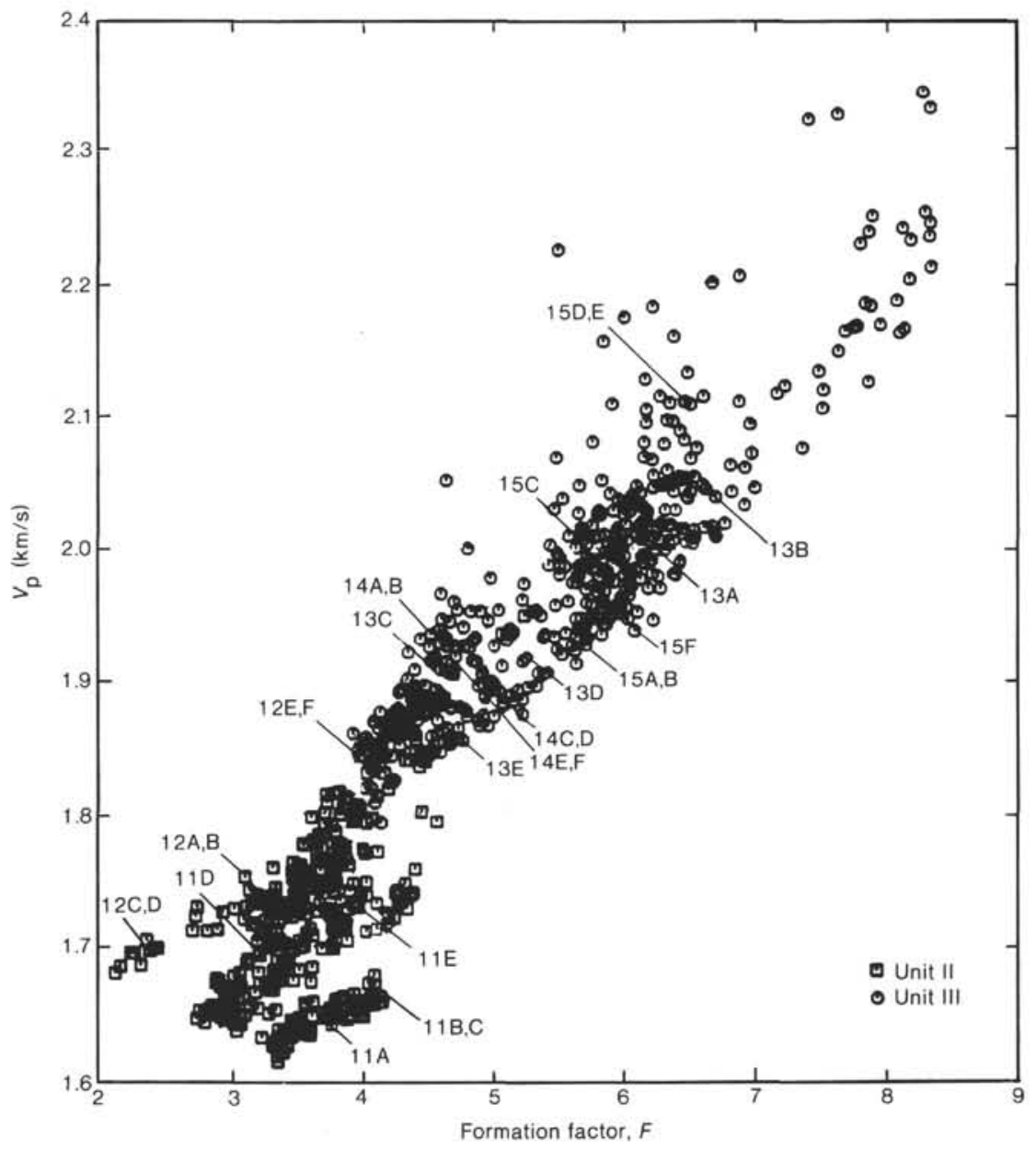

Figure 4. Crossplot of $V_{\mathrm{p}}$ and $F$ from Units II and III of Site 612. Numbers refer to figures showing samples.

in Figure 12. There is very little difference in the appearance of samples from just above and below the change from ooze to chalk (compare Figs. 11E and 12A, B), attesting to the gradual nature of the transition. Figure 12C, D (Sample 612-32-2, $71 \mathrm{~cm}$ ), however, is an example from a 5-m-thick layer that has an anomalously high porosity caused by an abundance of diatoms. At this depth ( $282 \mathrm{~m}$ sub-bottom) the diatoms are relatively pristine. Diatoms are well preserved (in greater or lesser abundance) until just above the appearance of opal-CT at the Unit II/Unit III boundary. At this boundary, within the space of only a few meters, a dramatic change in the sediment microstructure takes place. For example, Sample 612-36-2, $65 \mathrm{~cm}$ (Fig. 12E, F) is located at the change from chalk to porcellanitic chalk. In this sample, the chemical degradation of the siliceous biogenic grains is (or was) proceeding, but has not gone to completion. Only $4 \mathrm{~m}$ below this point the process is essentially complete (Sample 612-36-5, $67 \mathrm{~cm}$, Fig. 13A). The biogenic silica component of the sediment (opal-A) has dissolved and been reprecipitated as silica lepispheres (opal-CT). These lepispheres are ubiquitous, acting as a cement in the matrix of the sediment and also partially filling the remaining large calcareous tests. Sample porosities of 55 to $60 \%$ in Unit II drop to around $40 \%$ in Unit III, re- sulting in an increase in bulk density, even though the analyses show little change in the chemical makeup of the sediments (Fig. 1 and Thein and von Rad, this volume). Furthermore, the boundary is marked by several layers of porcellanitic limestone nodules with relatively high velocities. Below these layers velocity and formation factor increase, continuing the trend seen in the chalk of Unit II (Fig. 4).

The sediments of Unit III are described as nannofossil chalks, with porcellanitic chalk layers interbedded at several levels (Figs. 13-15). Several things are striking about the nature of the changes in these sediments versus those in Unit II, particularly the near total absence of biogenic silica. Biogenic silica presence in the original sediments is recorded by a few scattered dissolution-resistant microfossils (Figs. 14A, D) and also by the pyritized remains of diatom tests. This is illustrated by comparing the partially pyritized diatom test of Figure 12A, $\mathrm{B}$ with the diatom mold in the upper left hand corner of Figure 14C. Wise and Weaver (1974) studied similar silica reactions in Southern Ocean sediments and noted that once the dissolution-reprecipitation began, it went near to completion, and Hein et al. (1983) saw the same reactions in sediments of the equatorial eastern Pacific Ocean. It is important to note that these relationships are seen 


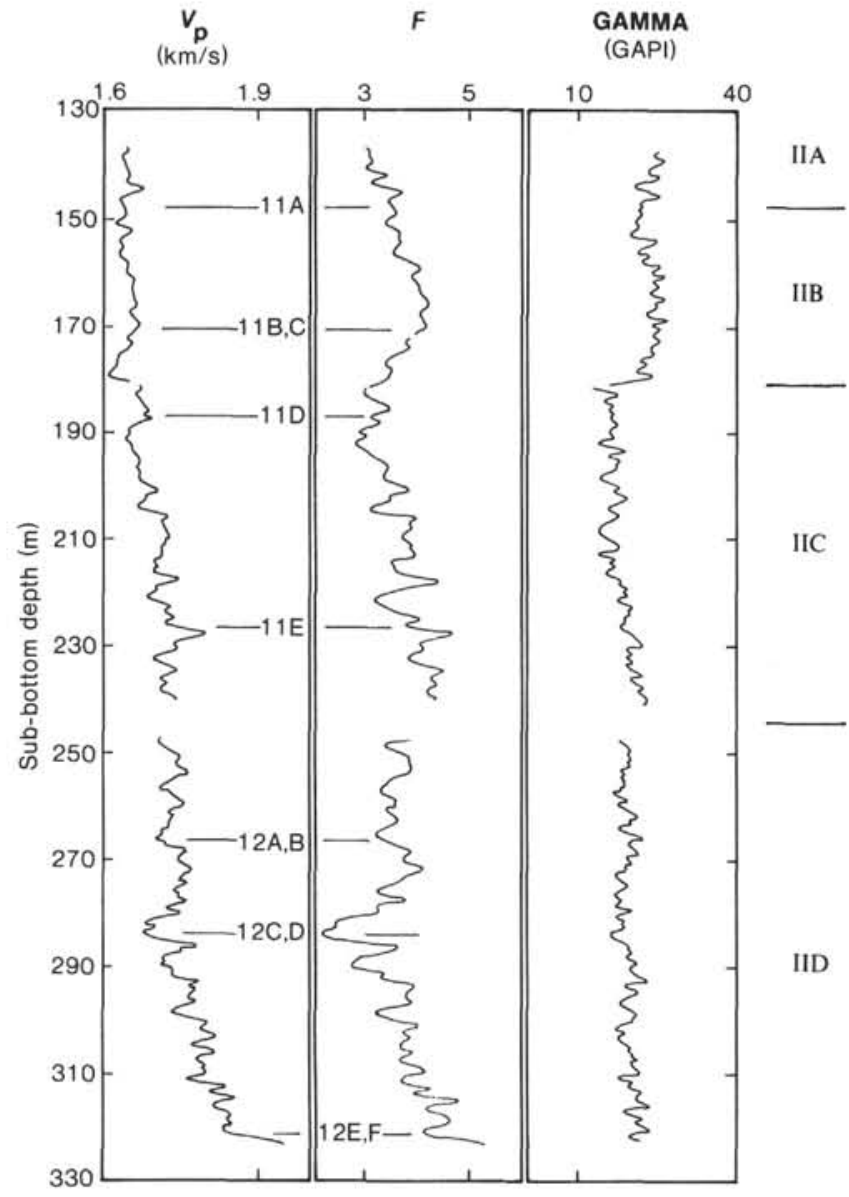

Figure 5. Plot of $V_{p}, F$, and gamma ray logs from Site 612, Unit II only. Numbers refer to figures showing samples. Gap in data from 240 to $247 \mathrm{~m}$ represents interval of borehole collapse. Subunits A, B, C, and D are identified on the basis of cross-plot of data (Fig. 6).

in siliceous carbonates, and that the silica-carbonate ratio appears to be an important factor in the diagenetic progression (Williams et al., 1985; Williams and Crerar, 1985).

Recent work suggests the importance of impurities in the recrystallization of biogenic opal (Williams et al., 1985; Williams and Crerar, 1985). The nature of the process involved in the dissolution and precipitation of silica at Site 612 may be triggered by some in situ threshold parameter (i.e., temperature, pressure, etc.) that affects all of the sediments below the diagenetic front. However, the widespread, approximately time-correlative, occurrence of this silica transition in North Atlantic sediments (Tucholke, 1981; Thein and von Rad, this volume) suggest that the diagenetic event may be linked to a basin-wide change in sediment and/or pore-water composition. If a change in sediment composition (such as clay content) is the major cause of the opal-A to opalCT transition, it is not a large enough change (volumetrically) to greatly influence sediment properties due to the intrinsic properties of the sediment components alone.

There are also some observational data on the sequence of precipitation of three primary authigenic phases in the Site 612 chalks and porcellanitic chalks. These phas- es, opaline silica, sparry calcite, and the zeolite clinoptilolite all occur within $10 \mathrm{~m}$ or so of the Unit II/Unit III boundary. An illustration of their crystallization history is seen in Figure 15E, a radiolarian mold. In this instance, the sparry calcite incorporates pre-existing clinoptilolite crystals and silica lepispheres. The clinoptilolite crystals show some small round holes suggesting that they also grew in the presence of the lepispheres. Other views illustrate the calcite-silica relationship (Figs. 14E, F, 15C, D) and the silica-clinoptilolite relationship (Fig. 14D). The question that is left unanswered by the data available is whether all three of these reactions were proceeding at approximately the same time, or whether they took place during separate time intervals and under differing environments.

Finally, it appears that while the silica reaction was triggered and went almost totally to completion, calcite dissolution and replacement increases gradually with depth. Studies of diagenesis in Equatorial Pacific pelagic sediments support the observation of a gradual change in calcite preservation with depth (Schlanger and Douglas, 1974; Manghnani et al., 1980). It appears that the calcite tests become increasingly corroded with depth while the void spaces are infilled with greater volumes of sparry calcite (compare Fig. 13 to Figs. 14E, F and 15; see Scholle, 1977). Thus, the initial increase in $V_{\mathrm{p}}$ and $F$ that occurs at the Unit II/Unit III boundary (particularly in the porcellanitic limestone nodules) may be primarily the effect of the change in state of the biogenic silica, whereas the gradual increase of $V_{\mathrm{p}}$ and $F$ with depth within Unit III is a response to an increase in the total amount of carbonate that has undergone dissolution and precipitation.

Lithologic Unit IV is characterized by the absence of both lepispheres and siliceous tests, as illustrated in Figure 16. Carbonate content of these samples is in excess of $60 \%$ for most of the unit and precipitation of sparry calcite appears to provide the mechanism for cementation, as well as the primary filling for preserved calcareous tests. Both Units IV and V have a large component of terrigenous material, particularly clays, and probably have a greater similarity to Unit I than the predominantly biogenic Units II and III. Thus, the trends in Units II and III need not necessarily continue into the lower sediments. There appears to be a greater preservation of calcareous tests in Unit IV than in the bottom of Unit III. This may be an effect of the terrigenous component of the sediment (mainly clays) slowing the dissolution and precipitation of calcite by either a decrease in permeability or adsorption of clays onto microfossil tests; an example of sediments having different diagenetic potentials.

\section{Site 613}

In general, the same diagenetic trend is seen in Unit II samples from Site 613 as at Site 612, with the exception that clinoptilolite, ubiquitous at lower levels of Site 612 as a pore-filling phase, is seen only in XRD analyses at Site 613 (Fig. 17). Throughout the section, there is weak dissolution of both carbonate and opal-A tests. Siliceous and calcareous fragments, as well as coccolith 


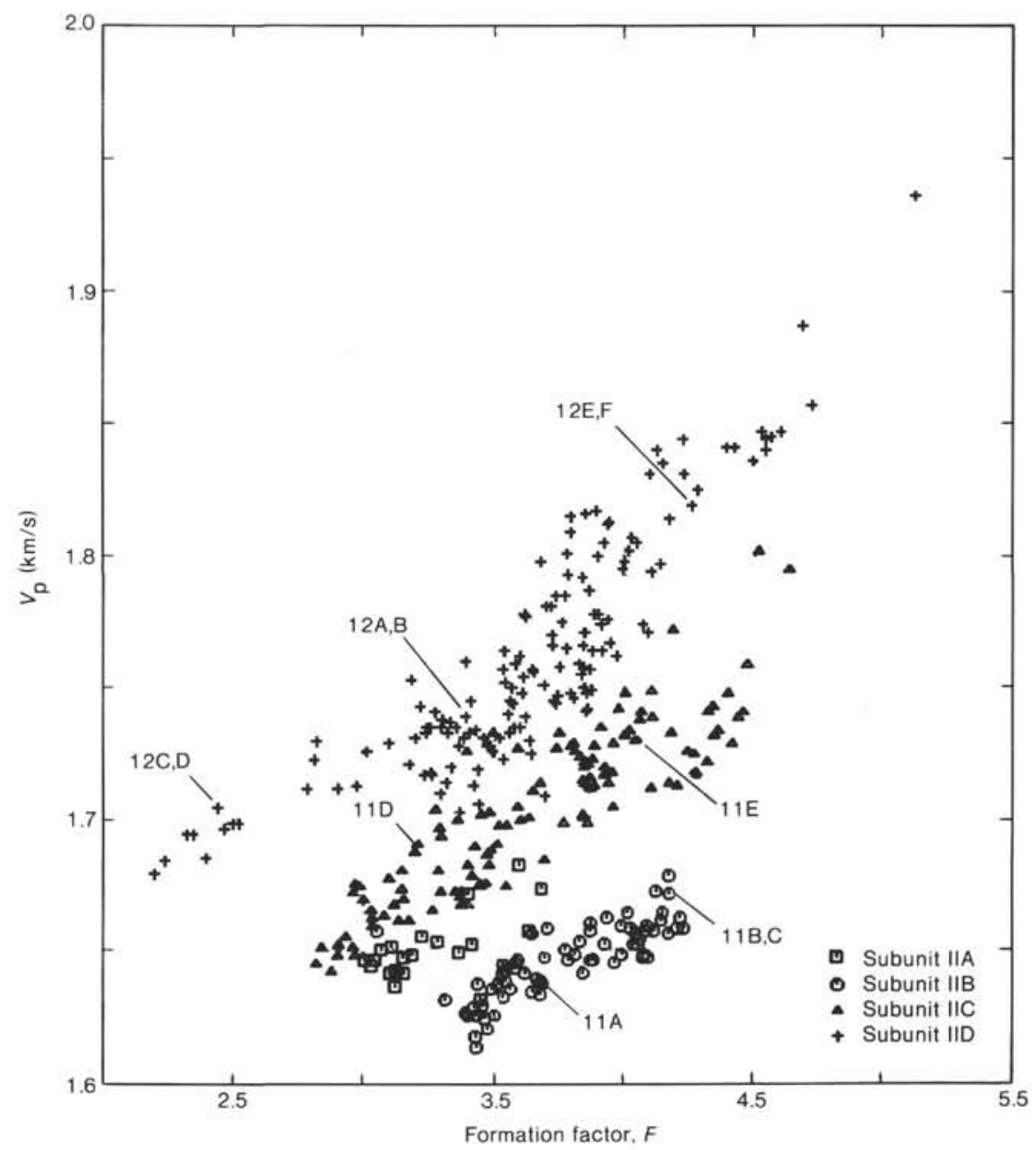

Figure 6. Plot of $V_{\mathrm{p}}$ and $F$ from Figure 5. Numbers refer to figures showing samples. Subunits are discrete depth intervals.

platelets, comprise much of the matrix (compare Figs. 17B and 18D). A few meters above the appearance of opal-CT, the siliceous components begin to degrade extensively (Fig. 17C).

\section{SLUMP STRUCTURES-A SPECIAL CASE}

Several slump structures were identified in the sediment column of Site 613 . The slumps are interesting because they seem to show a different diagenetic history than the sediments above and below them in the lithologic column, although their initial composition was the same. Within the slump at the bottom of Unit II (Fig. $18 \mathrm{~A}, \mathrm{~B})$, it is observed that siliceous tests have either dissolved or have been replaced by calcite, yet there are no relic tests that are filled with lepispheres, as there were at Site 612, or are in Unit III of Site 613, only $6 \mathrm{~m}$ lower in the sediment column (Fig. 18C, D). Instead, sparry calcite fills calcified radiolarian tests (Fig. 18B), while just below, a similar radiolarian test has been dissolved and filled with silica lepispheres (Fig. 18D). Similar variations in the diagenetic history of slumped shelf and slope sediments have been observed in outcrops (Alvarez et al., 1985).

Deeper into Unit III of Site 613, much the same diagenetic pattern is seen as at Site 612. Initial precipitation of silica lepispheres is followed by subsequent calcite formation (Fig. 18E, F). Sparry calcite becomes more abundant as a pore filling material as depth increases (Fig. $19)$, and there are very few unfilled or partially filled tests left in the sediment framework in the deepest samples examined.

\section{CONCLUSIONS}

With the exception of the slump deposits, the trends in the alteration of sediment microstructure are generally the same at Sites 612 and 613 . Sediments at both sites exhibit an apparently abrupt dissolution of biogenic silica and a more gradual change in the form of calcite present. Synthetic seismograms (Goldberg et al., this volume) suggest that the zone of silica transition corresponds to a seismic reflector that may be equivalent to a major North Atlantic reflector, Horizon $\mathrm{A}^{\mathrm{c}}$ (Tucholke, 1981). Compaction, in the sense of a purely mechanical process that crushes and reorders grains into a more compact microstructure, is not observed to be important in reducing sediment porosity at depths greater than 100 $\mathrm{m}$. Many of the radiolarian, diatom, and foraminifer tests remain intact through the ooze to chalk transition. The open (unfilled by matrix) tests contribute as much as $15-20 \%$ to sediment porosity. Chalks have higher ve- 


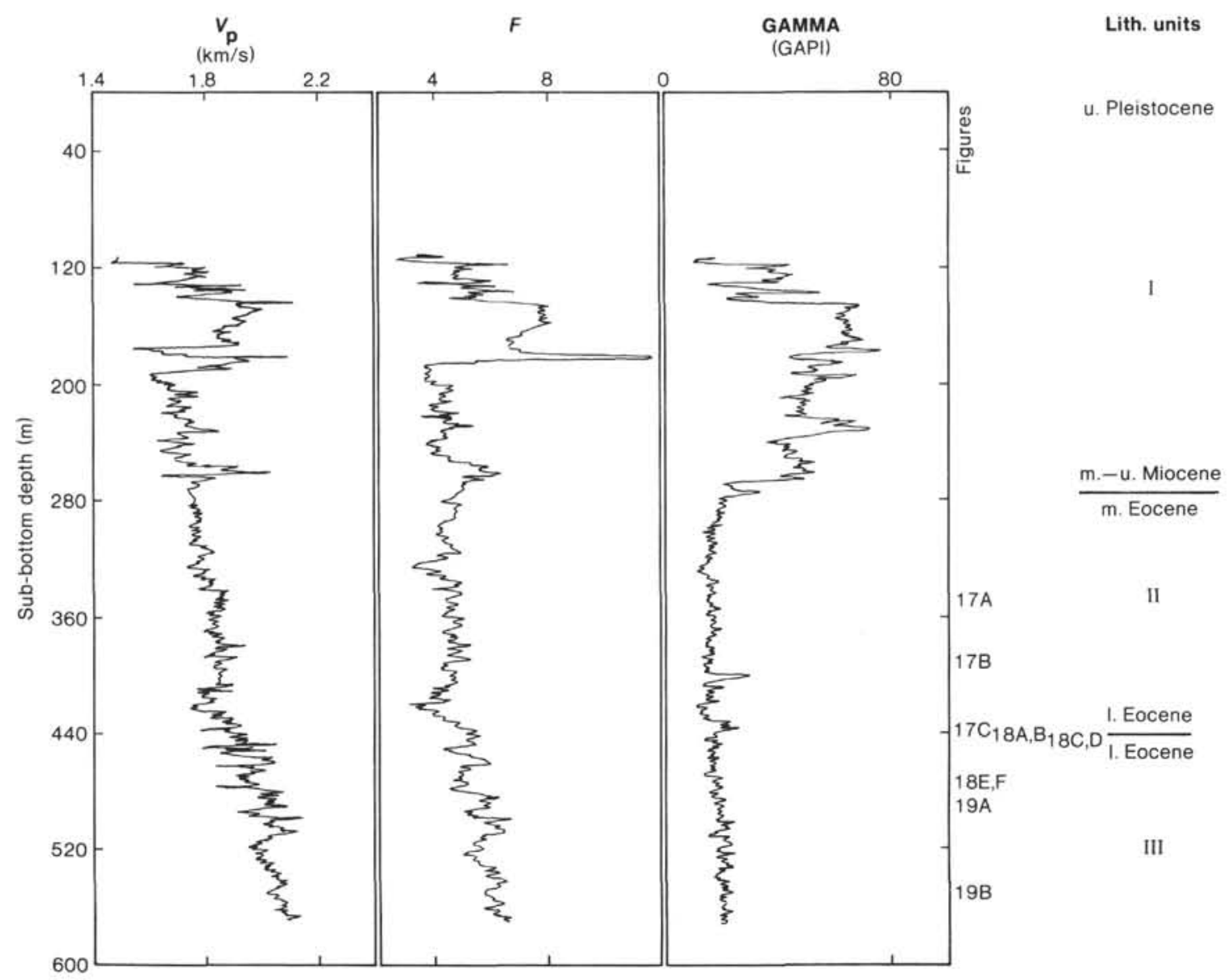

Figure 7. Well-log data of $V_{p}, F$, and gamma ray counts plotted versus sub-bottom depth for Site 613. Numbers refer to figures showing samples.

locities than oozes with the same formation factor, indicating weak cementation of the chalk framework. However, it is the appearance of opal-CT that constitutes the major change in microstructure. The sediment continues to increase in velocity, owing to matrix cementation by opaline lepispheres, and in bulk density, as a result of a significant porosity reduction.

Results of this study are not necessarily common to diagenetic histories of sediments on a worldwide scale. Two sites that have shared depositional and postdepositional histories and sediment compositions, however, appear to have undergone similar patterns of alteration. A better understanding of these histories and their relationship to microstructures and physical properties of the sediments at Sites 612 and 613 will lead to improved interpretation of seismic data from the western Atlantic margin, and in other areas that have similar settings.

\section{ACKNOWLEDGMENTS}

We wish to thank the officers and crew of the Glomar Challenger and the DSDP technical staff for the smooth operation of the ship and science facilities. Tom Birtley was particularly helpful in sorting out the raw logging data. Arthur Cheng, of ERL, has provided insights and advice during the course of this work. Lori Williams and Edwin L. Hamilton provided helpful reviews. This work was funded by NSF grant $\# 84087610 \mathrm{CE}$ and by the Full Waveform Acoustic Logging Consortium of the Earth Resources Laboratory.

\section{REFERENCES}

Alvarez, W., Colacicchi, R., and Montanari, A., 1985. Synsedimentary slides and bedding formation in Apennine pelagic limestones. J. Sediment. Petrol., 55:720-734.

Bachmann, R. T., 1984. Intratest porosity in foraminifera. J. Sediment. Petrol., 54:257-262.

Berryman, J. G., 1981. Elastic wave propagation in fluid saturated porous media. J. Acoust. Soc. Amer., 69:416-424.

Boyce, R. E., 1976. Definitions and laboratory techniques of compressional sound velocity parameters and wet-water content, wetbulk density and porosity parameters by gravimetric and gamma ray attenuation techniques. In Schlanger, S. O., and Jackson, E. D., Init. Repts. DSDP, 33: Washington (U.S. Govt. Printing Office), 695-728.

Bryant, W. R., Hoffman, W. and Trabant, P., 1975. Permeability of unconsolidated marine sediments, Gulf of Mexico. Mar. Geotech., $1: 1-14$.

Ernst, W. G., and Calvert, S. E., 1969. An experimental study of the recrystallization of porcellanite and its bearing on the origin of some bedded cherts. Am. J. Sci., 267-A:114-133.

Hearst, J. R., and Nelson, P. H., 1985. Well Logging for Physical Properties: New York (McGraw-Hill).

Hein, J. R., Sancetta, C., and Morgenson, L. A., 1983. Petrology and geochemistry of silicified upper Miocene chalk, Costa Rica Rift, DSDP Leg 69. In Cann, J. R., Langseth, M. G., et al., Init. Repts. $D S D P, 69$ : Washington (U.S. Govt. Printing Office), 395-422.

Jim, C. Y., 1985. Impregnation of moist and dry unconsolidated clay samples using Spurr resin for microstructural studies. J. Sediment. Petrol., 55:597-599.

Kuster, G. T., and Toksöz, M. N., 1974. Velocity and attenuation of seismic waves in two phase media: Part 1. Theoretical formulations. Geophysics, 39:587-606. 
Manghnani, M. H., Schlanger, S. O., and Milholland, P. D., 1980. Elastic properties related to depth of burial, strontium content and age, and diagenetic stage in pelagic carbonate sediments. In $\mathrm{Ku}-$ perman, W. A. and Jensen, F. B., (Eds.), Bottom-Interacting Ocean Acoustics: New York (Plenum).

Mayer, L. A., 1979. Deep sea carbonates: acoustic, physical, and stratigraphic properties. J. Sediment. Petrol., 49:819-836.

Ogushwitz, P. R., 1985. Applicability of the Biot theory. III. Wave speed versus depth in marine sediments. J. Acoust. Soc. Amer., 77: 453-464.

Reich, V., and von Rad, U., 1979. Eocene porcellanites and early Cretaceous cherts from the western North Atlantic basin. In Tucholke, B. E., Vogt, P. R., et al., Init. Repts. DSDP, 43: Washington (U.S. Govt. Printing Office), 437-448.

Schlanger, S. O., and Douglas, R. G., 1974. The pelagic ooze-chalklimestone transition and its implications for marine stratigraphy. In Hsü, K. J., and Jenkyns, H. C. (Eds.) Pelagic Sediments on Land and Under the Sea (Vol. 1): London (Int. Assoc. Sediment.), 117-148.

Scholle, P. A., 1977. Chalk diagenesis and its relation to petroleum exploration: oil from chalks, a modern miracle? Am. Assoc. Pet. Geol. Bull., 61:982-1009.

Schreiber, B. C., 1968. Sound velocity in deep sea sediments. J. Geophys. Res., 73:1259-1268.

Serra, O., 1984. Fundamentals of Well-Log Interpretation: New York (Elsevier).

Spurr, A. R., 1969. A low-viscosity epoxy resin embedding for electron microscopy. J. Ultrastructure Res., 26:31-43.
Timur, A. and Toksöz, M. N., 1985. Downhole geophysical logging. Ann. Rev. Earth Planet. Sci., 13:315-344.

Toksöz, M. N., Cheng, C. H., and Timur, A., 1976. Velocities of seismic waves in porous rocks. Geophysics, 41:621-645.

Tucholke, B. E., 1981. Geologic significance of seismic reflectors in the deep western North Atlantic basin. Soc. Econ. Paleontol. Mineral. Spec. Publ., 32:23-37.

Ward, S. H., and Fraser, D. C., 1967. Conduction of electricity in rocks. In Hansen, D. A., Heinreichs, W. E., Holmer, R. C., MacDougall, R. E., Rodgers, G. E., et al. (Eds.), Mining Geophysics (Vol. II): Tulsa (Soc. Exp. Geol.), 198-223.

Wilkens, R. H., and Handyside, T., 1985. Physical properties of equatorial Pacific sediments. In Mayer, L., and Theyer, F., et al., Init. Repts. DSDP, 85: Washington (U.S. Govt. Printing Office), 839847.

Williams, L. A., and Crerar, D. A., 1985. Silica diagenesis, II. General mechanisms. J. Sediment. Petrol., 55:312-321.

Williams, L. A., Parks, G. A., and Crerar, D. A., 1985. Silica diagenesis, I. solubility controls. J. Sediment. Petrol., 55:301-311.

Wise, S. W., and Weaver, F. M., 1974. Chertification of oceanic sediments. In Hsü, K. J., and Jenykns, H. C. (Eds.), Pelagic Sediments on Land and Under the Sea (Vol. 1): London (Int. Assoc. Sediment.), 301-326.

Date of Initial Receipt: 17 September 1985 Date of Acceptance: 8 January 1986

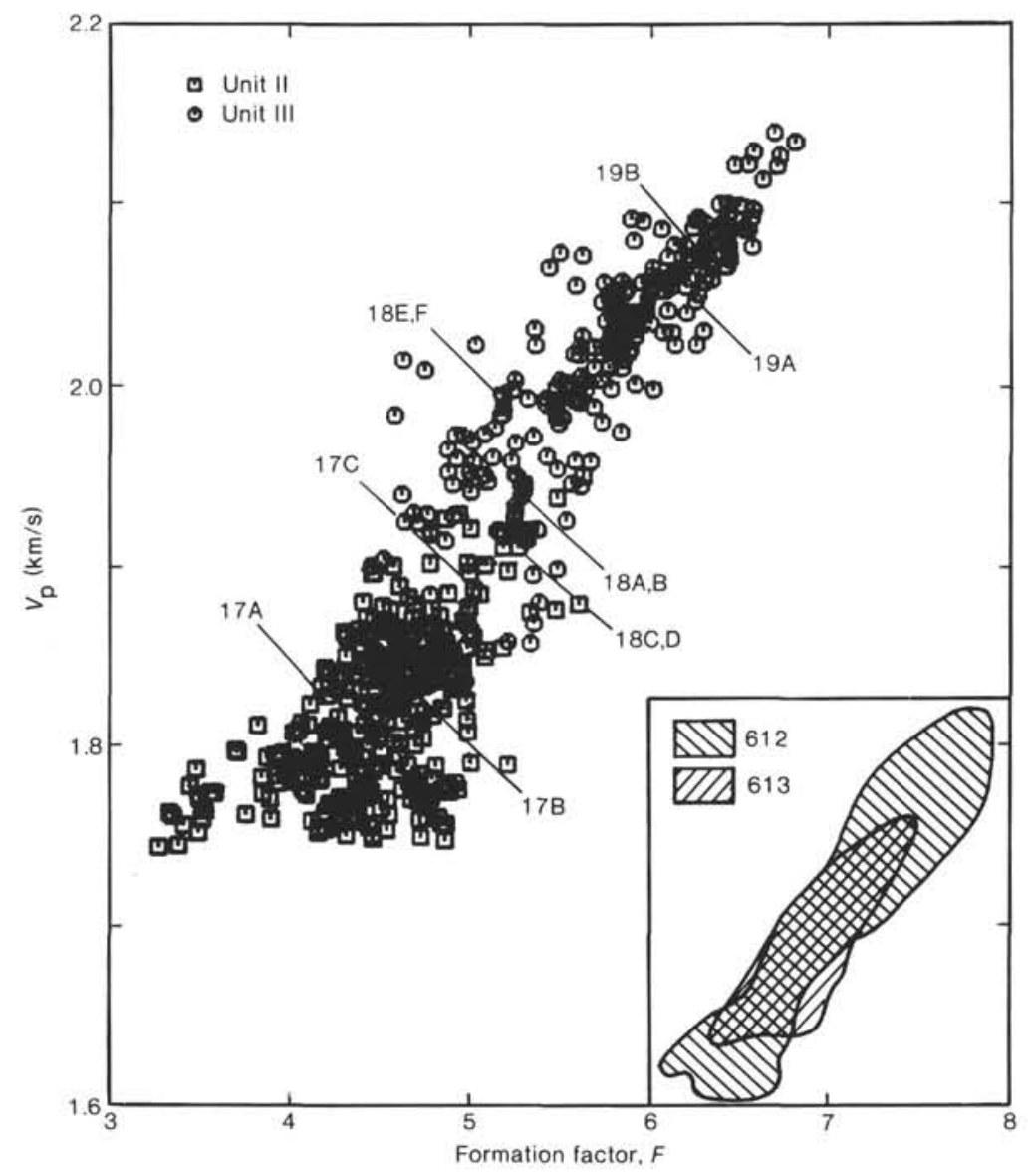

Figure 8. Crossplot of data from Figure 7. Numbers refer to figures showing samples. Inset is overlay of data fields of Sites 612 and 613. 


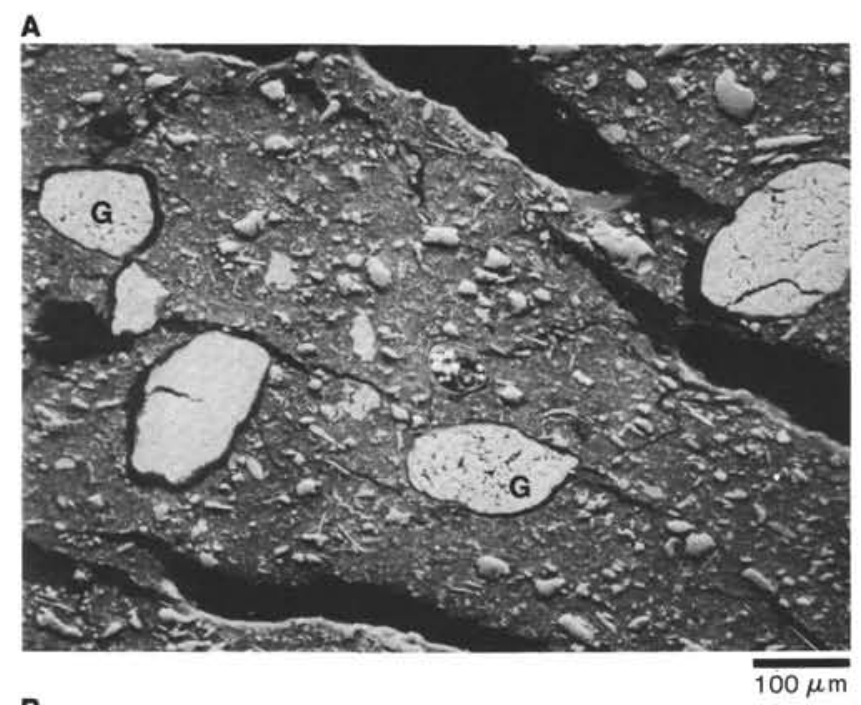

\section{B}

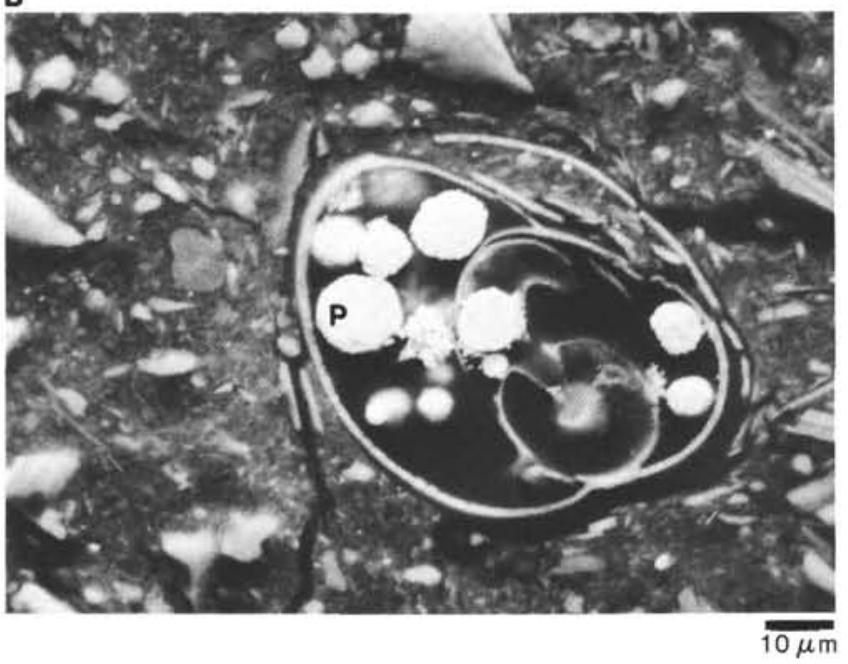

Figure 9. Sample 612-8-1, $70 \mathrm{~cm}(\sim 53 \mathrm{~m} \mathrm{SBD})$. Porosity $=54 \%$, $\mathrm{CaCO}_{3}=1 \%$. Unit IA, upper Pliocene, massive mud. A. Abundant quartz silt and authigenic glauconite $(G)$, rare foraminifers (arrow). Scale bar $=100 \mu \mathrm{m}$. B. Detail of foraminifer illustrating pyrite framboids $(\mathrm{P})$ formed inside test. Scale bar $=10 \mu \mathrm{m}$. Scanning electron microscope photomicrographs of backscattered electron images. Porosity and carbonate content values from samples adjacent to SEM samples. Unit designations and sediment type from core descriptions. 
A

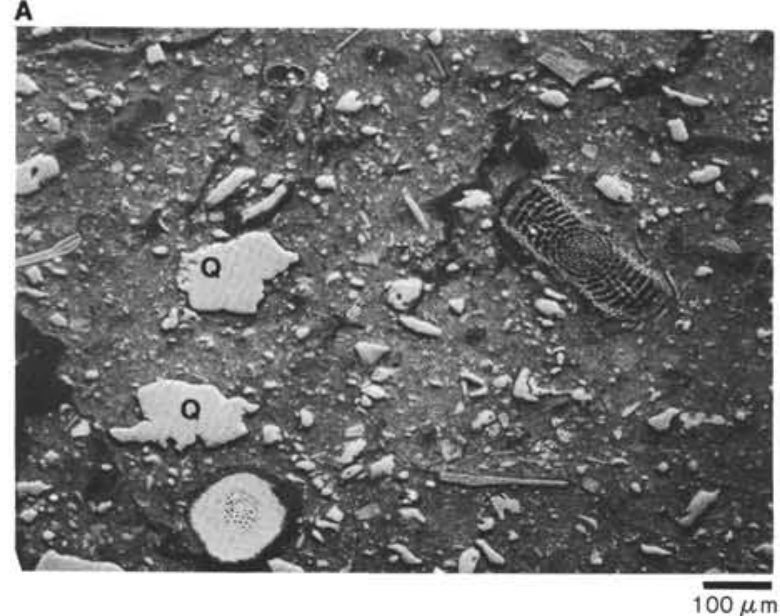

B

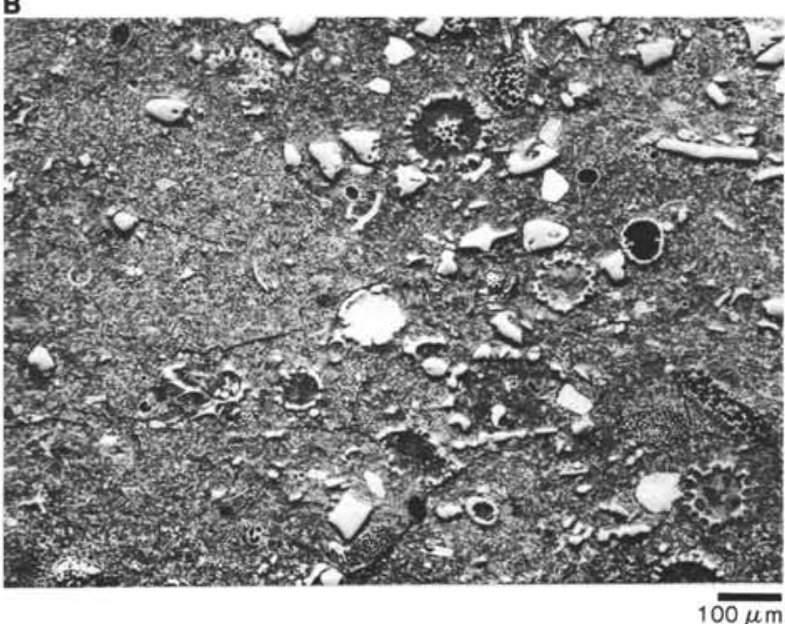

\section{C}

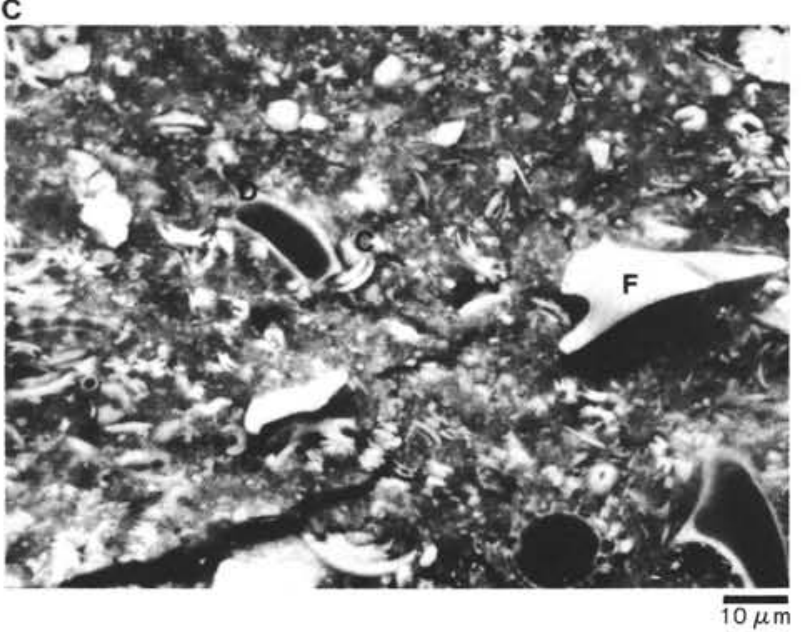

Figure 10. A. Sample 612-14-2, $70 \mathrm{~cm}(\sim 110 \mathrm{~m} \mathrm{SBD})$. Porosity $=57 \%, \mathrm{CaCO}_{3}=2 \%$. Unit IB, upper Miocene, micaceous mud. Abundant angular and embayed quartz sand $(\mathrm{Q})$ and silt with several percent foraminifers, diatoms, and radiolarians. Scale bar $=$ $100 \mu \mathrm{m}$. B. Sample 612-16-2, $71 \mathrm{~cm}(\sim 129 \mathrm{~m} \mathrm{SBD})$. Porosity $=52 \%, \mathrm{CaCO}_{3}=5 \%$. Unit IB, upper Miocene, radiolarian (foraminiferal) nannofossil ooze. Mixed assemblage of carbonate clasts, foraminifer and radiolarian tests, quartz, feldspar, and amphibole grains. Scale bar $=100 \mu \mathrm{m}$. C. Same sample as B; detail of matrix containing diatoms (D), coccolith plates (Cc), foraminifer fragments (F), and undifferentiated silt- and clay-sized material. Scale bar $=10 \mu \mathrm{m}$. Scanning electron microscope photomicrographs of backscattered electron images. Porosity and carbonate content values from samples adjacent to SEM samples. Unit designations and sediment type from core descriptions. 
A

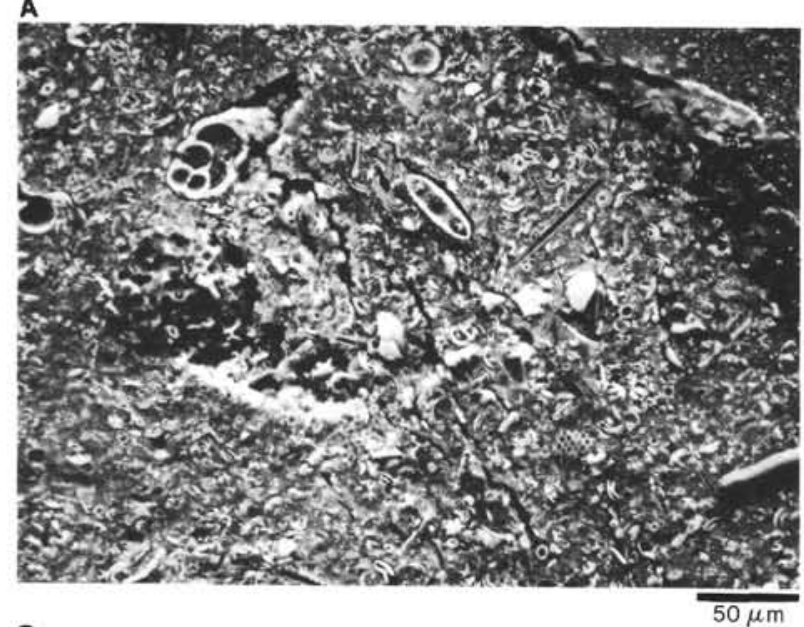

C

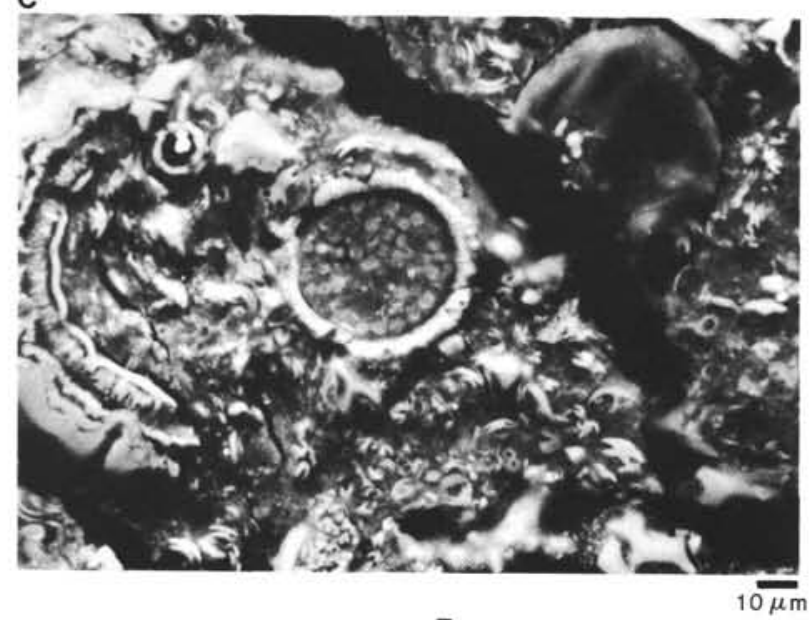

B

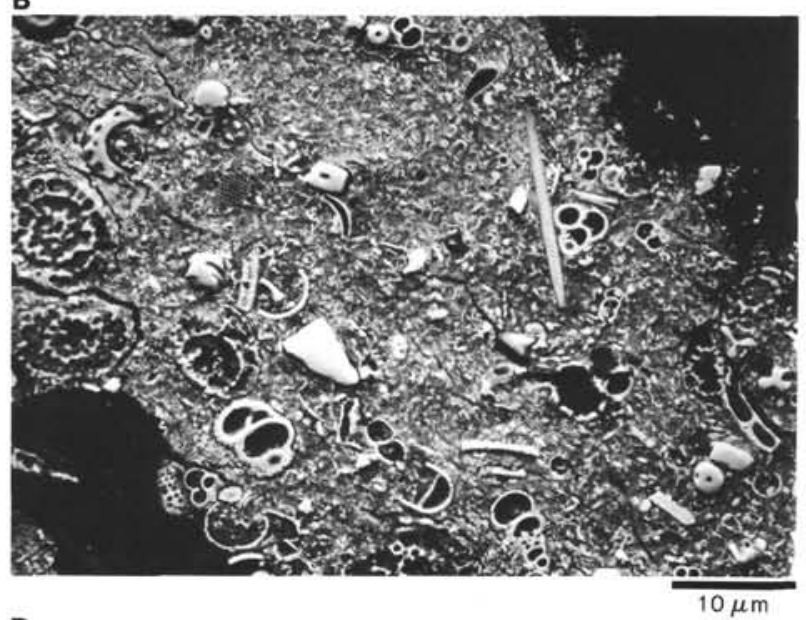

D

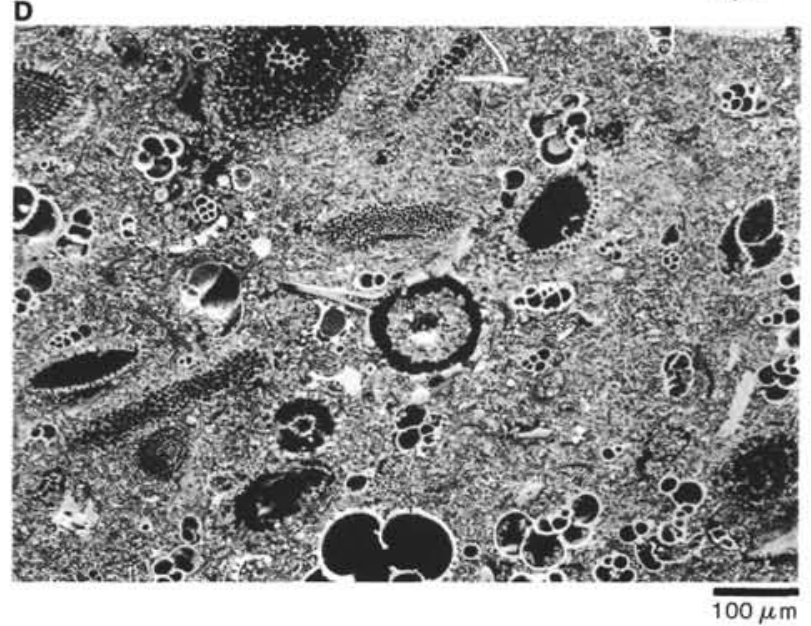

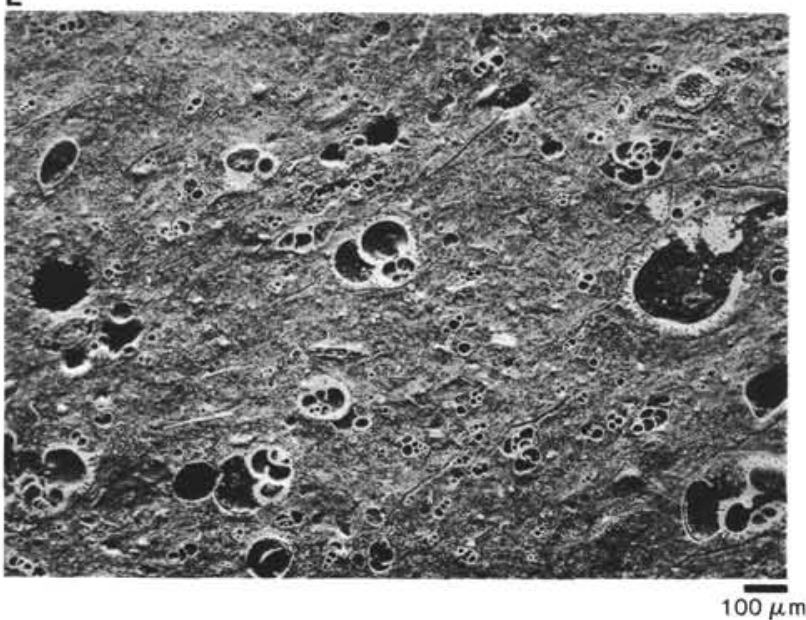

Figure 11. A. Sample 612-18-2, $72 \mathrm{~cm}(\sim 148 \mathrm{~m} \mathrm{SBD})$. Porosity $=63 \%, \mathrm{CaCO}_{3}=45 \%$. Unit II, upper Eocene, siliceous foraminiferal nannofossil ooze. Abundant radiolarian, foraminifer, and diatom tests. Matrix contains abundant coccolith platelets and biogenic test fragments. Scale bar $=50 \mu \mathrm{m}$. B. Sample 612-20-2, $74 \mathrm{~cm}(\sim 170 \mathrm{~m} \mathrm{SBD})$. Porosity $=58 \%, \mathrm{CaCO}_{3}=38 \%$. Unit II, upper Eocene, siliceous nannofossil ooze. Corroded radiolarian tests, well preserved foraminifer tests. Sponge spicule upper right, feldspar grain center. Scale bar $=100 \mu \mathrm{m}$. C. Same sample; detail of matrix, including abundant coccolith platelets and biogenic fragments. Test in center has been filled with authigenic minerals containing $\mathrm{K}, \mathrm{Si}, \mathrm{Al}, \mathrm{Mg}, \mathrm{Ti}$, and $\mathrm{Fe}$; perhaps a complex zeolite. Scale bar $=10 \mu \mathrm{m}$. D. Sample 612-22-2, $59 \mathrm{~cm}(\sim 186 \mathrm{~m} \mathrm{SBD})$. Porosity $=60 \%, \mathrm{CaCO}_{3}=49 \%$. Unit II, upper middle Eocene, siliceous, foraminiferal nannofossil ooze. Tests exhibit very little corrosion or infilling. Scale bar $=100 \mu \mathrm{m}$. E. Sample $612-26-2,77 \mathrm{~cm}(\sim 224 \mathrm{~m} \mathrm{SBD})$. Porosity $=59 \%, \mathrm{CaCO}_{3}=44 \%$. Unit II, middle Eocene, siliceous nannofossil chalk. Both large and small foraminifer tests are present. Diatoms show some corrosion and have collapsed. Most tests remain unfilled. Scale bar $=100 \mu \mathrm{m}$. Scanning electron microscope photomicrographs of backscattered electron images. Porosity and carbonate content values from samples adjacent to SEM samples. Unit designations and sediment type from core descriptions. 
A

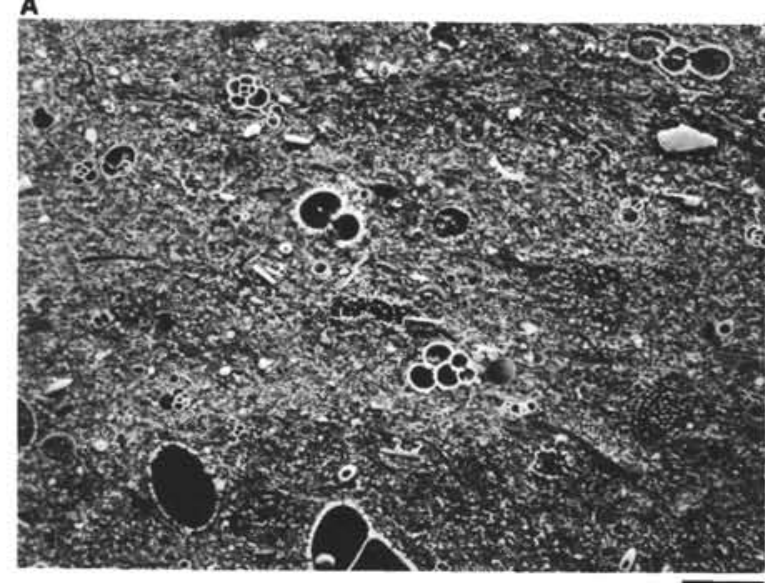

C

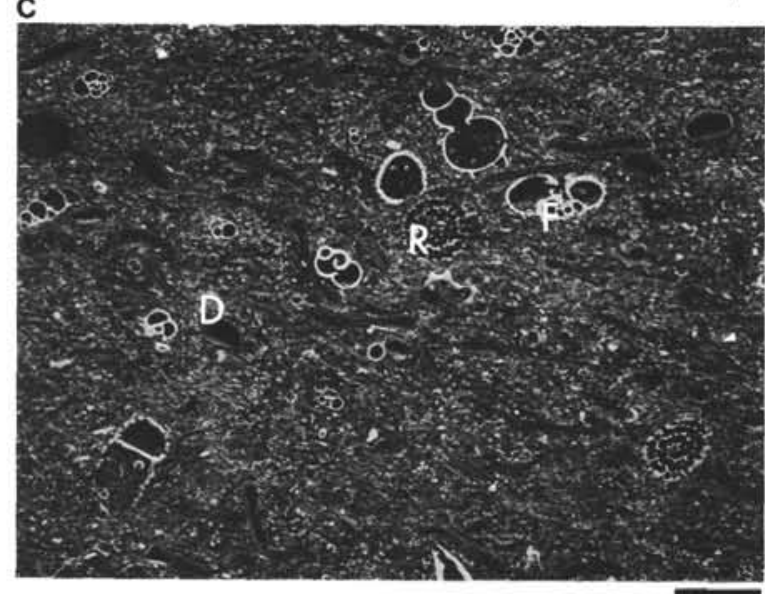

E

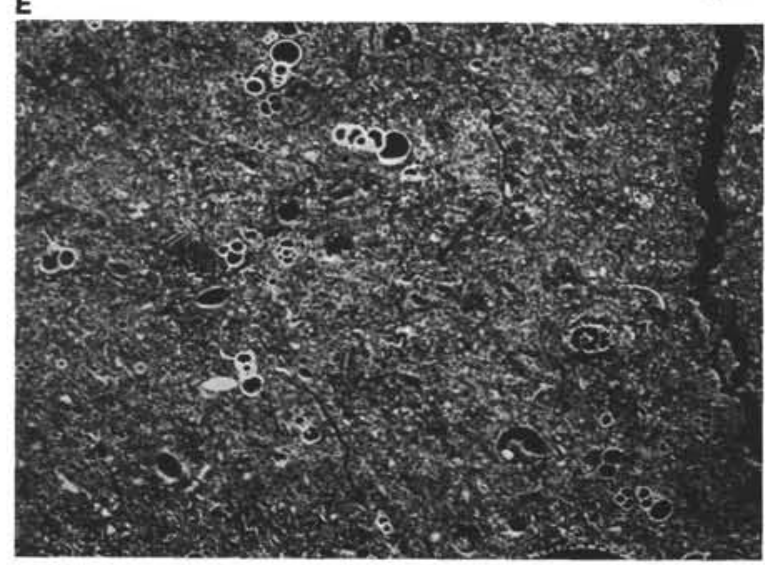

B

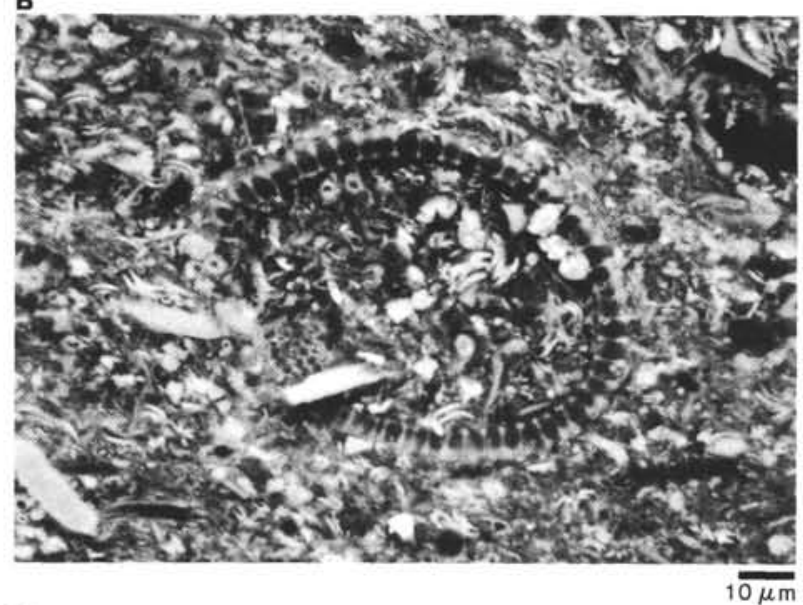

D

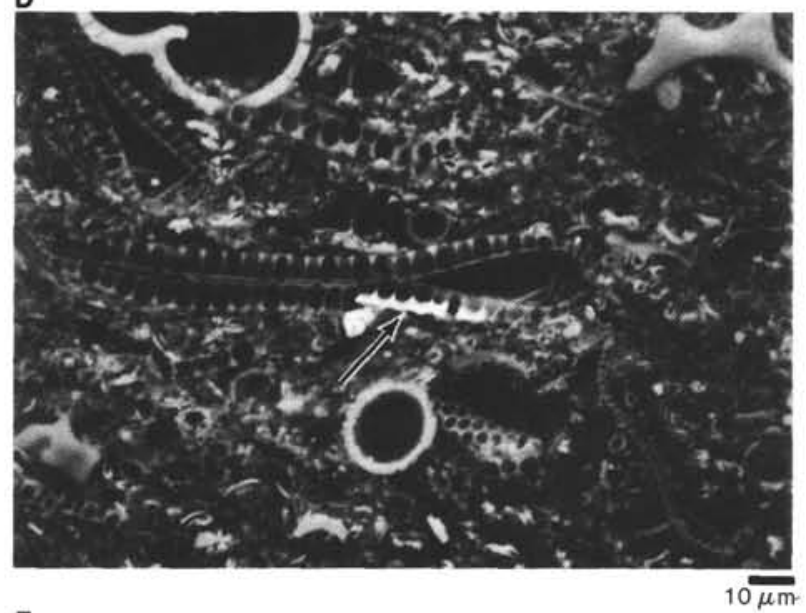

$\mathbf{F}$

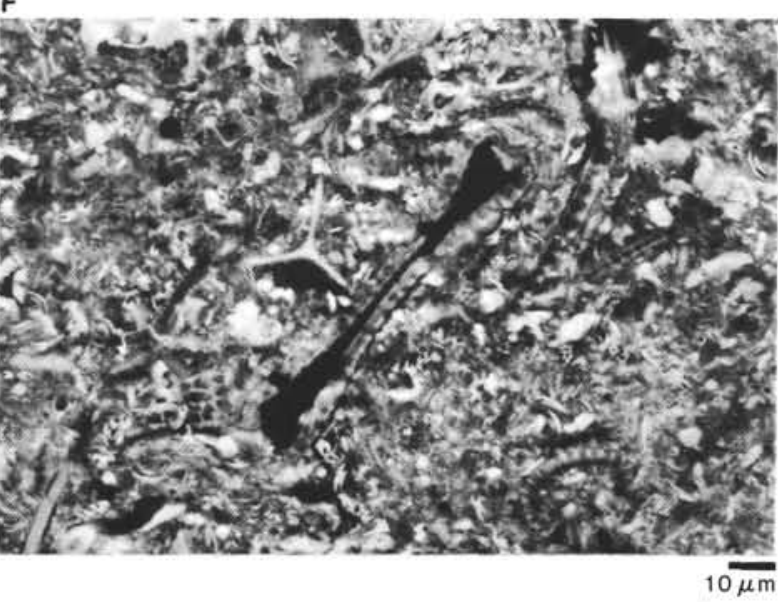

Figure 12. A. Sample 612-30-3, $70 \mathrm{~cm}(\sim 264 \mathrm{~m} \mathrm{SBD})$. Porosity $=59 \%, \mathrm{CaCO}_{3}=45 \%$. Unit II, middle Eocene, siliceous nannofossil chalk. Many open tests of radiolarians and foraminifers, as well as flattened diatoms. Scale bar $=100 \mu \mathrm{m}$. B. Same sample; detail of matrix. Diatom test has been breached and infilled with matrix of coccolith platelets and test fragments. Scale bar $=10$ $\mu \mathrm{m}$. C. Sample 612-32-2, $71 \mathrm{~cm}(\sim 282 \mathrm{~m} \mathrm{SBD})$. Porosity $=65 \%, \mathrm{CaCO}_{3}=45 \%$. Unit II, middle Eocene, siliceous nannofossil chalk. Open tests of foraminifers (F), radiolarians (R), and diatoms (D). Flattened diatom test in center is partially pyritized. Scale bar $=100 \mu \mathrm{m}$. D. Detail of center of C. Bright area replacing crushed diatom test is pyrite (arrow). Scale bar $=10 \mu \mathrm{m}$. E. Sample $612-36-2,65 \mathrm{~cm}(\sim 321 \mathrm{~m} \mathrm{SBD})$. Porosity $=53 \%, \mathrm{CaCO}_{3}=49 \%$. Unit II, middle Eocene, siliceous nannofossil chalk. Open foraminifer tests and flattened diatom tests. Siliceous components are beginning to show extensive dissolution. Scale bar $=100 \mu \mathrm{m}$. F. Detail of upper right center of E. Flattened diatom test, as well as other siliceous components of the matrix, are partially dissolved. Scale bar $=10 \mu \mathrm{m}$. Scanning electron microscope photomicrographs of backscattered electron images. Porosity and carbonate content values from samples adjacent to SEM samples. Unit designations and sediment type from core descriptions. 
A

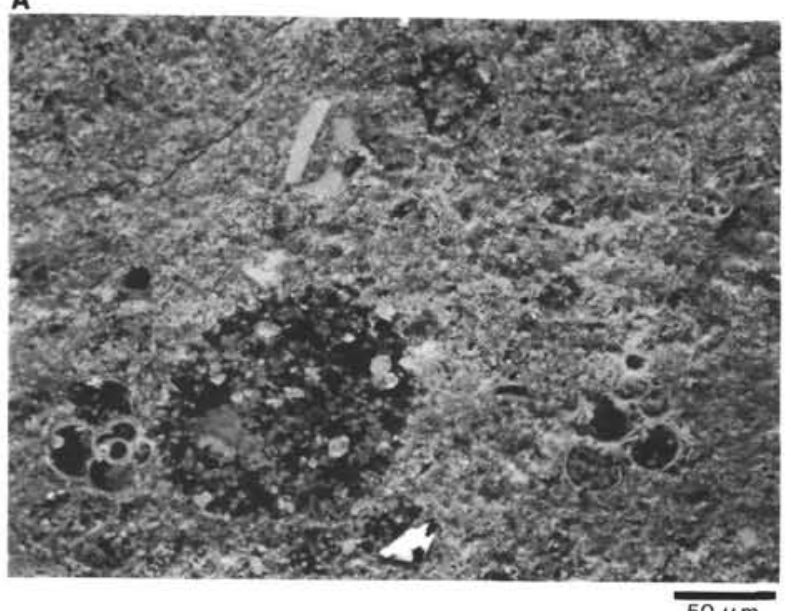

C

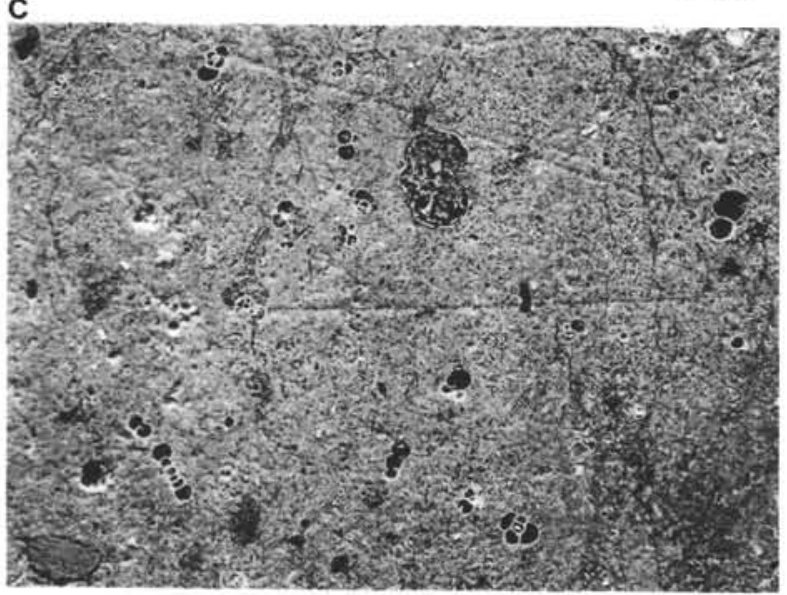

B

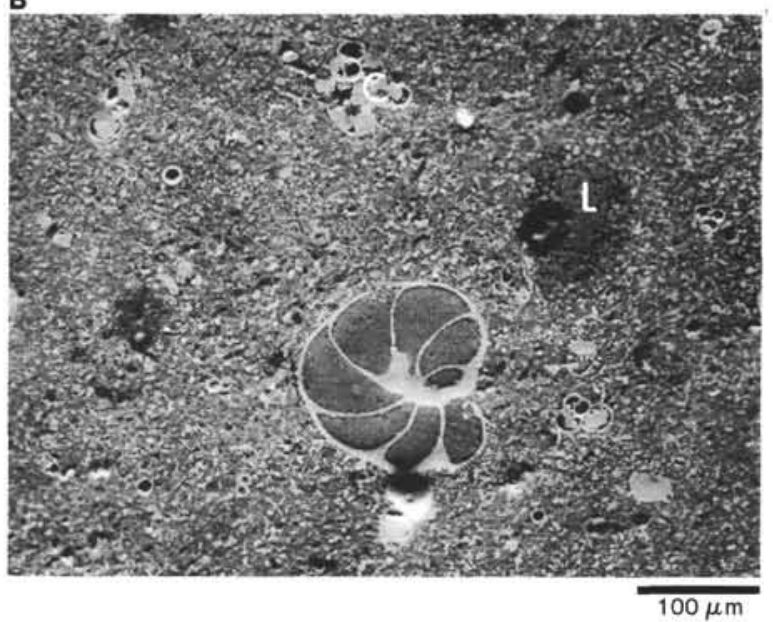

D

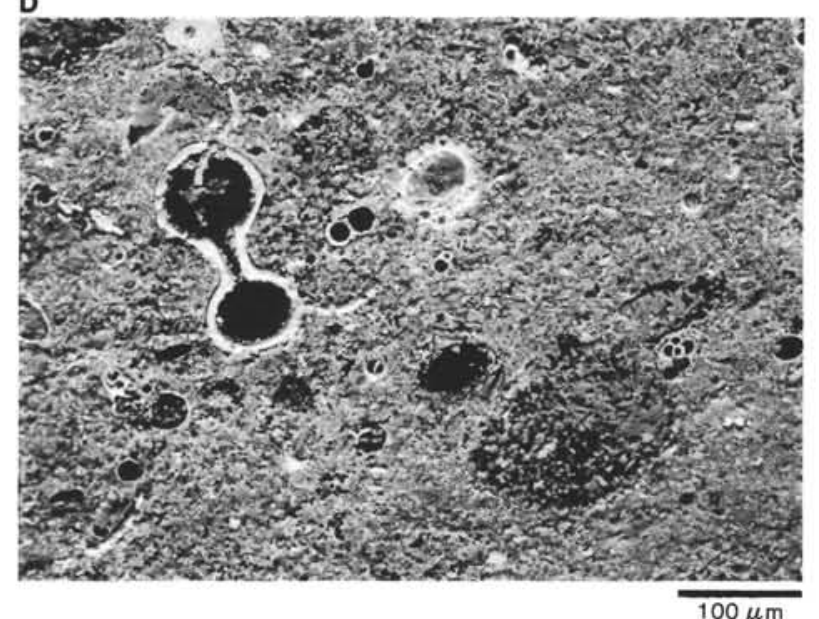

E

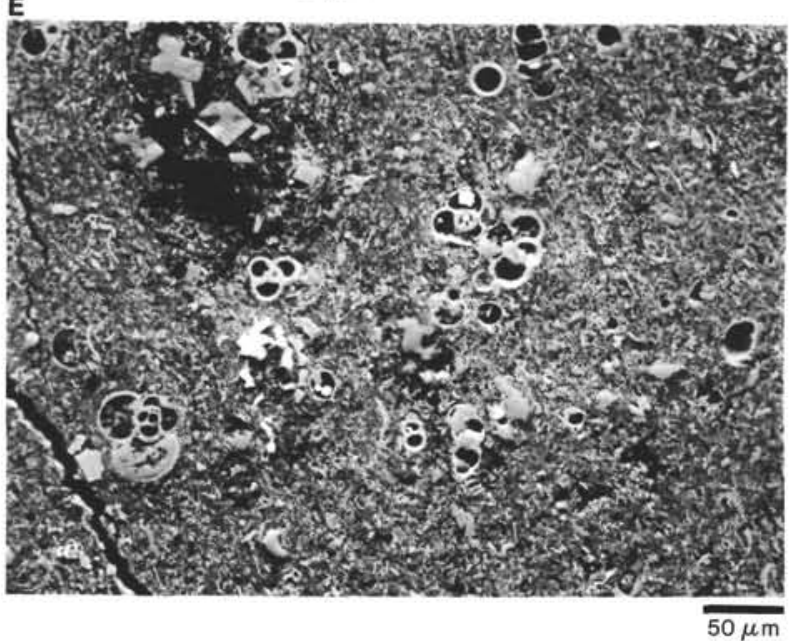

Figure 13. A. Sample 612-36-5, $67 \mathrm{~cm}(\sim 325 \mathrm{~m} \mathrm{SBD})$. Porosity $=43 \%, \mathrm{CaCO}_{3}=49 \%$. Unit III, middle Eocene, siliceous foraminiferal nannofossil chalk. Voids in the sediment held open by calcareous tests are partially filled with siliceous lepispheres (arrows). Scale bar $=50 \mu \mathrm{m}$. B. Sample 612-37-2, $70 \mathrm{~cm}(\sim 332 \mathrm{~m} \mathrm{SBD})$. Porosity $=55 \%, \mathrm{CaCO}_{3}=39 \%$. Unit III, upper lower Eocene, siliceous foraminiferal nannofossil chalk. Foraminifer tests have been partially filled with both silica lepispheres (L) and sparry calcite (C). Scale bar $=100 \mu \mathrm{m}$. C. Sample 612-37-4, $60 \mathrm{~cm}(\sim 333 \mathrm{~m} \mathrm{SBD})$. Porosity $=38 \%, \mathrm{CaCO}_{3}=21 \%$. Unit III, upper lower Eocene, siliceous foraminiferal nannofossil chalk. Lepisphere-filled and open tests. Sparry calcite is absent in this sample. Scale bar $=100 \mu \mathrm{m}$. D. Sample 612-37-5, $40 \mathrm{~cm}(\sim 334 \mathrm{~m} \mathrm{SBD})$. Porosity $=45 \%, \mathrm{CaCO}_{3}=40 \%$. Unit III, upper lower Eocene, siliceous foraminiferal nannofossil chalk. Many foraminifer tests remain open, but others, as well as molds of radiolarians and diatoms, are filled with lepispheres. Scale bar $=100 \mu \mathrm{m}$. E. Sample 612-37-6, $120 \mathrm{~cm}(\sim 336 \mathrm{~m} \mathrm{SBD})$. Porosity $=37 \%, \mathrm{CaCO}_{3}=40 \%$. Unit III, upper lower Eocene, siliceous nannofossil chalk. Lepispheres and zeolites (Z; probably clinoptilolite) fill tests. Scale bar $=50$ $\mu \mathrm{m}$. Scanning electron microscope photomicrographs of backscattered electron images. Porosity and carbonate content values from samples adjacent to SEM samples. Unit designations and sediment type from core descriptions. 
A

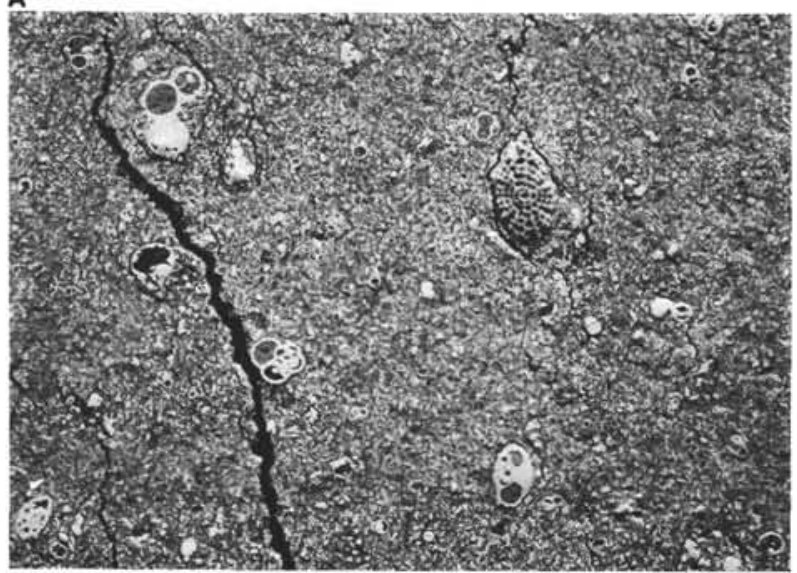

C

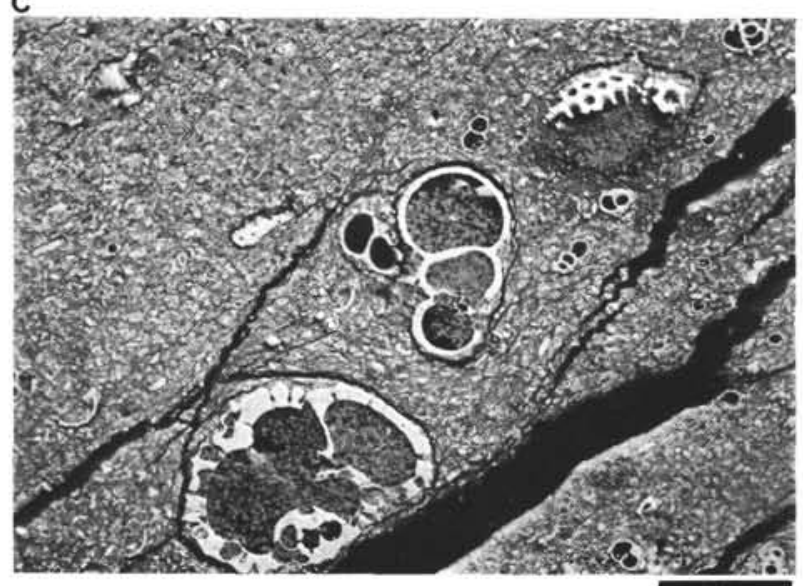

$\mathbf{E}$

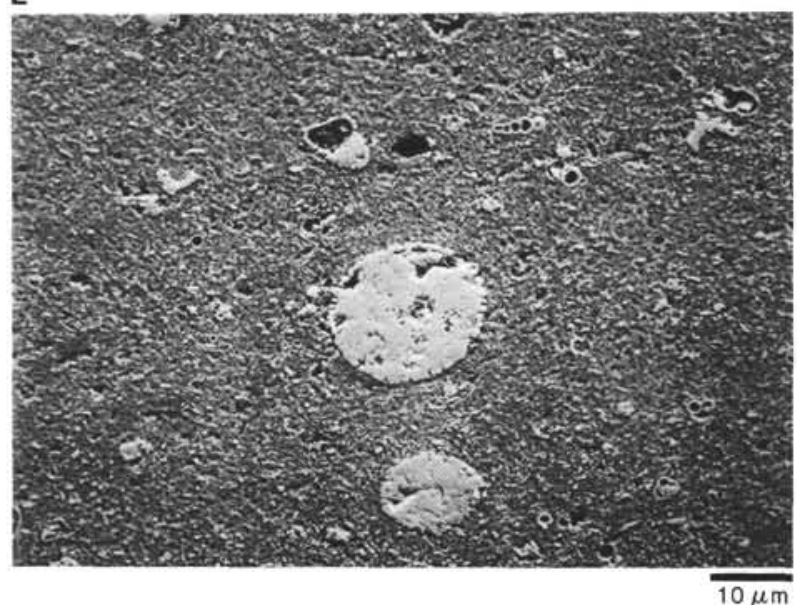

B

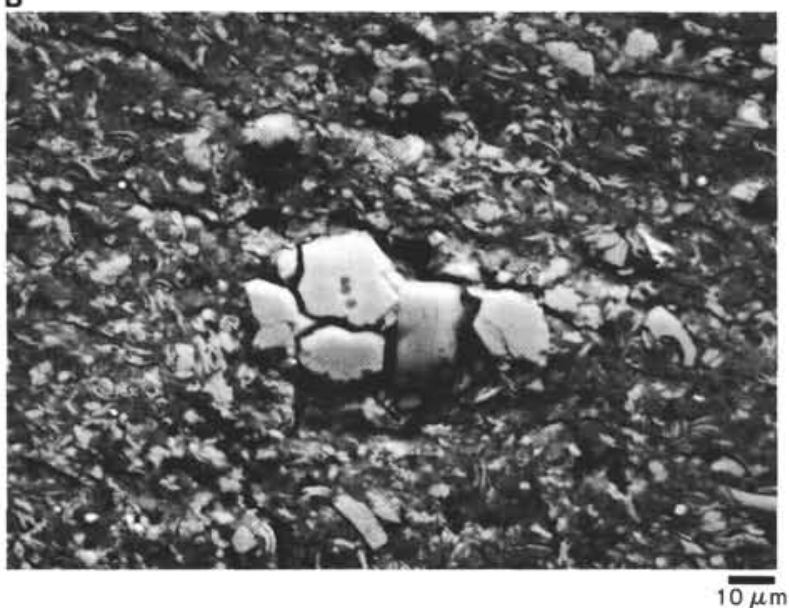

D

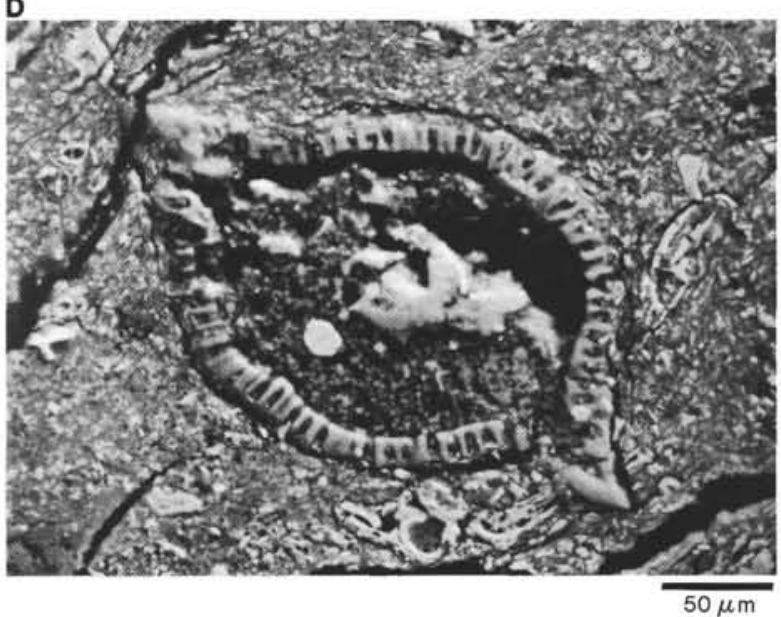

F

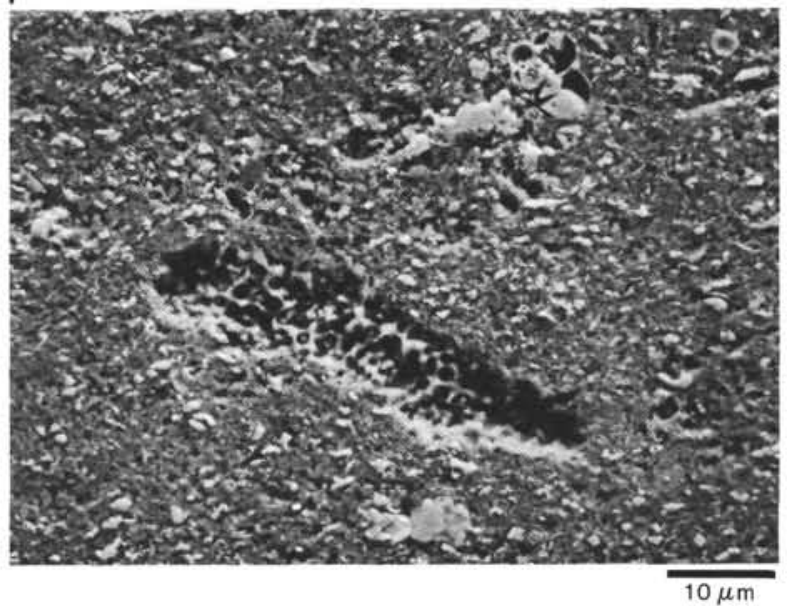

Figure 14. A. Sample 612-40-2, $70 \mathrm{~cm}(\sim 359 \mathrm{~m} \mathrm{SBD})$. Porosity $=44 \%, \mathrm{CaCO}_{3}=55 \%$. Unit III, upper lower Eocene, siliceous nannofossil chalk. Foraminifer tests are partially calcite and lepisphere filled. Resistant radiolarian test (R) in upper right. Scale bar $=$ $100 \mu \mathrm{m}$. B. Same sample; radiolarian mold filled with sparry calcite. Note that the matrix now contains an abundance of lepispheres. Scale bar $=10 \mu \mathrm{m}$. C. Sample $612-42-4,75 \mathrm{~cm}(\sim 382 \mathrm{~m} \mathrm{SBD})$. Porosity $=48 \%, \mathrm{CaCO}_{3}=43 \%$. Unit III, upper lower Eocene, siliceous nannofossil chalk. Lepisphere filled foraminifer tests. Note in upper right: mold of diatom filled with lepispheres and partially pyritized test (compare to Fig. 12D). Scale bar $=100 \mu \mathrm{m}$. D. Same sample; resistant radiolarian test filled with lepispheres (L), clinoptilolite (Z), and pyrite (P). Scale bar $=50 \mu \mathrm{m}$. E. Sample 612-44-4, $100 \mathrm{~cm}(\sim 401 \mathrm{~m}$ SBD). Porosity $=43 \%$, $\mathrm{CaCO}_{3}=40 \%$. Unit III, upper lower Eocene, siliceous nannofossil chalk. Most tests are filled with calcite and/or lepispheres. Scale bar $=100 \mu \mathrm{m}$. F. Same sample; rare radiolarian relic, severely corroded. Scale bar $=10 \mu \mathrm{m}$. Scanning electron microscope photomicrographs of backscattered electron images. Porosity and carbonate content values from samples adjacent to SEM samples. Unit designations and sediment type from core descriptions. 
A

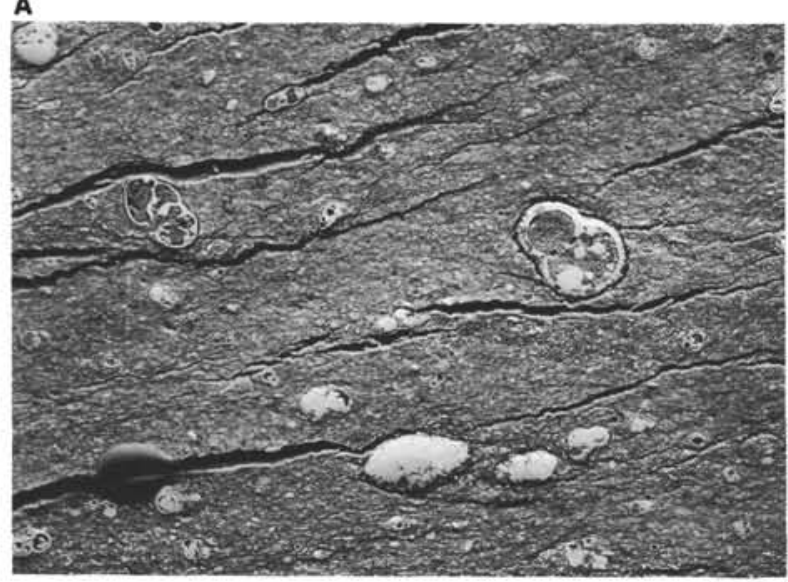

C

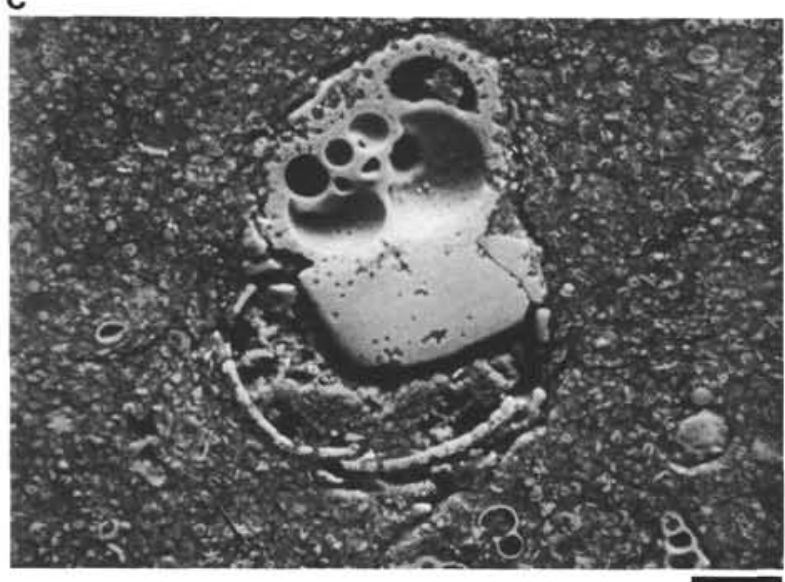

$\mathbf{E}$

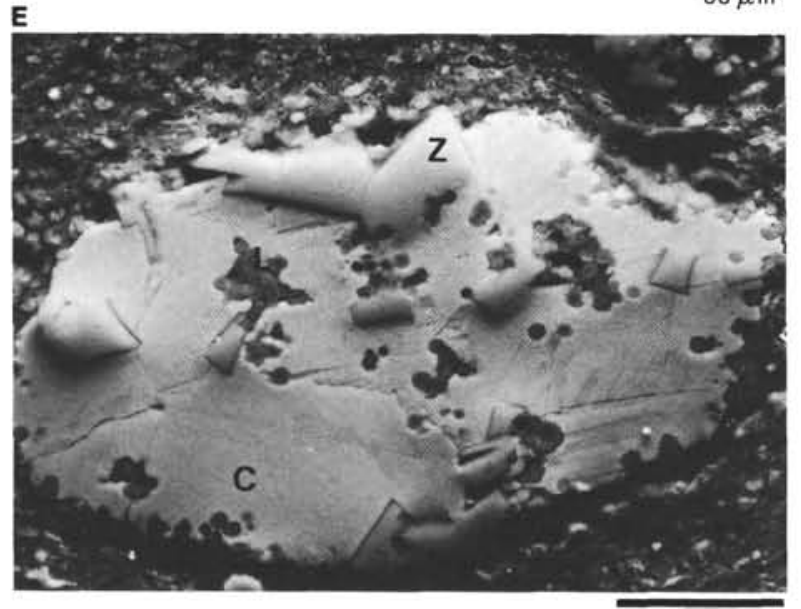

$50 \mu \mathrm{m}$
B

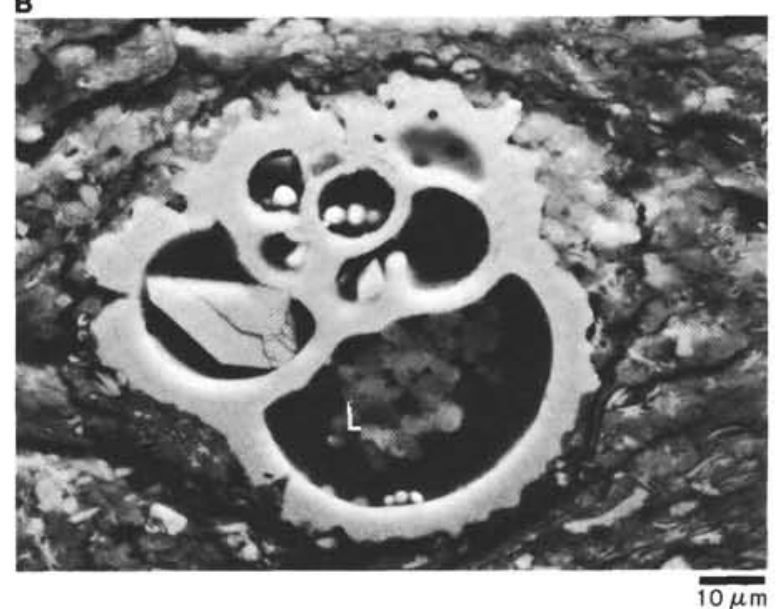

D

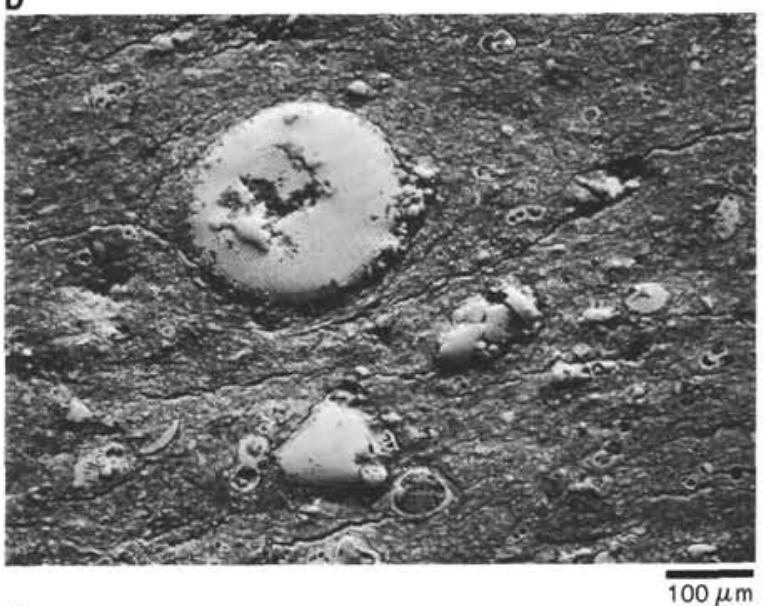

$\mathbf{F}$

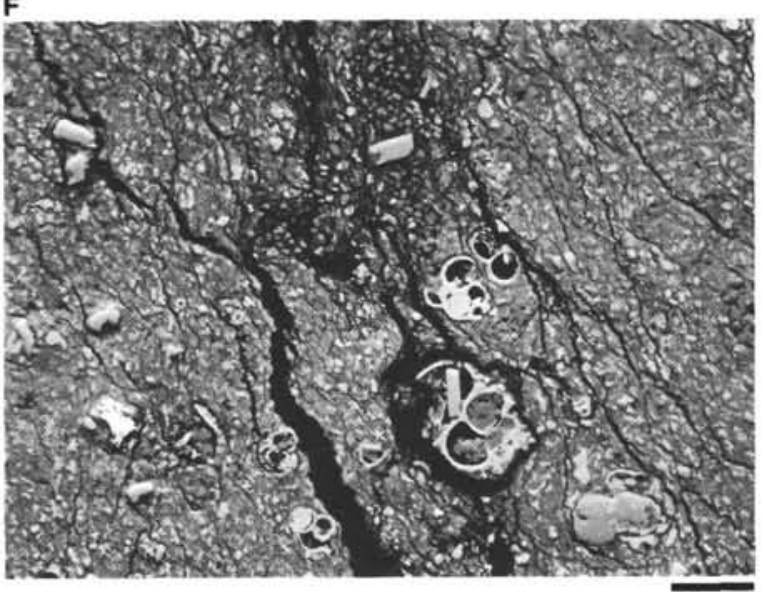

Figure 15. A. Sample 612-46-2, $75 \mathrm{~cm}(\sim 417 \mathrm{~m} \mathrm{SBD})$. Porosity $=41 \%, \mathrm{CaCO}_{3}=44 \%$. Unit III, lower Eocene, siliceous nannofossil chalk. Most voids have been completely filled with calcite and lepispheres. Scale bar $=100 \mu \mathrm{m}$. B. Same sample, foraminifer test partially filled with sparry calcite (C), pyrite framboids (P), and lepispheres (L). Scale bar $=10 \mu \mathrm{m}$. C. Sample $612-48-2,70 \mathrm{~cm}$ ( $\sim 37 \mathrm{~m} \mathrm{SBD})$. Porosity $=41 \%, \mathrm{CaCO}_{3}=49 \%$. Unit III, middle lower Eocene, siliceous nannofossil chalk. Corroded foraminifer test partially filled by sparry calcite and lepispheres. Note "holes" in calcite where it crystallized around lepispheres. Scale bar $=50 \mu \mathrm{m}$. D. Sample 612-50-2, $71 \mathrm{~cm}(\sim 456 \mathrm{~m} \mathrm{SBD})$. Porosity $=39 \%, \mathrm{CaCO}_{3}=52 \%$. Unit III, middle lower Eocene, siliceous foraminiferal nannofossil chalk. Radiolarian mold filled with interlocking sparry calcite, clinoptilolite, and lepispheres. Scale bar $=100 \mu \mathrm{m}$. E. Same sample; detail showing relationship between authigenic phases. Calcite (C) has grown around clinoptilolite (Z) and lepispheres (L). Scale bar $=50 \mu \mathrm{m}$. F. Sample 612-56-2, $70 \mathrm{~cm}(\sim 514 \mathrm{~m} \mathrm{SBD})$. Porosity $=45 \%, \mathrm{CaCO}_{3}=33 \%$. Unit III, low er middle Eocene, siliceous nannofossil chalk. Tests and molds of tests filled with calcite, clinoptilolite, and lepispheres. Scale bar $=50 \mu \mathrm{m}$. Scanning electron microscope photomicrographs of backscattered electron images. Porosity and carbonate content values from samples adjacent to SEM samples. Unit designations and sediment type from core descriptions. 

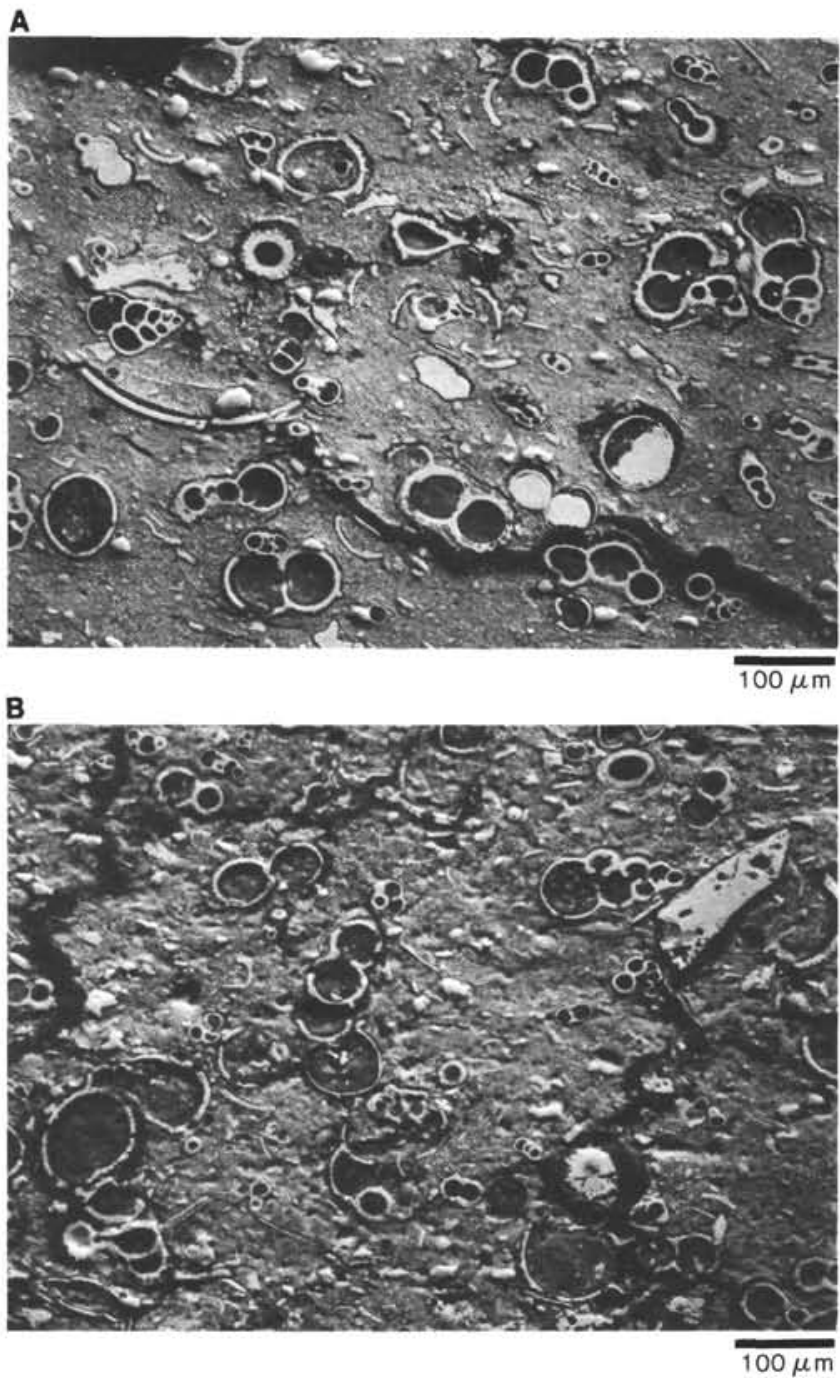

Figure 16. A. Sample $612-66-2,75 \mathrm{~cm}(\sim 610 \mathrm{~m} \mathrm{SBD})$. Porosity $=$ $41 \%, \mathrm{CaCO}_{3}=55 \%$. Unit IV, middle Maestrichtian, marly foraminiferal nannofossil chalk. Foraminifer tests partially filled with sparry calcite and clay. Scale bar $=100 \mu \mathrm{m}$. B. Sample 612-68-2, $65 \mathrm{~cm}(\sim 629 \mathrm{~m}$ SBD $)$. Porosity $=46 \%, \mathrm{CaCO}_{3}=47 \%$. Unit IV, Maestrichtian, marly nannofossil foraminiferal chalk. Clay and minor calcite fillings of foraminifer tests. Scale bar $=100 \mu \mathrm{m}$. Scanning electron microscope photomicrographs of backscattered electron images. Porosity and carbonate content values from samples adjacent to SEM samples. Unit designations and sediment type from core descriptions. 
A

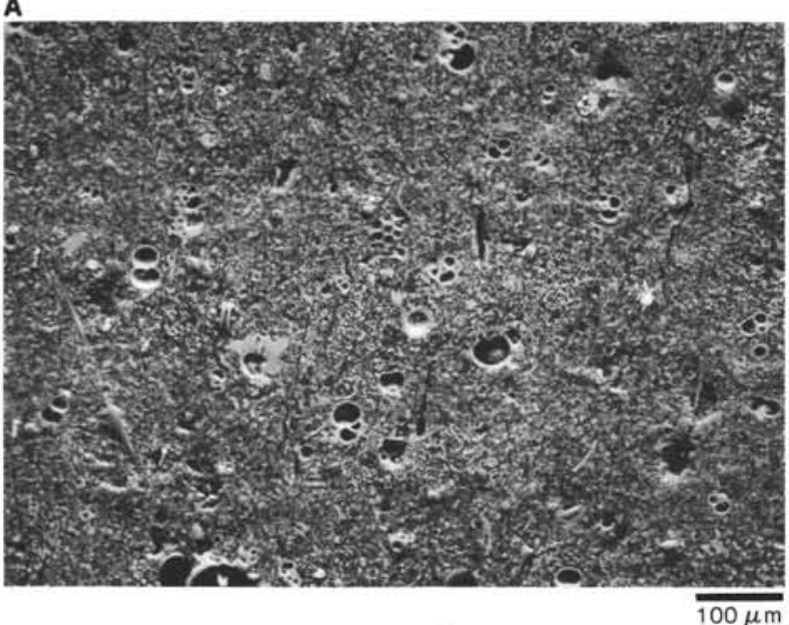

C

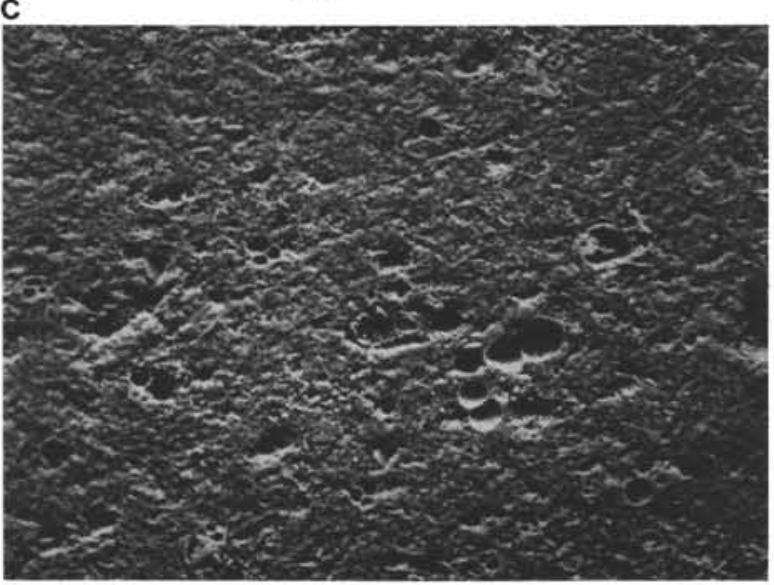

$\overline{100 \mu \mathrm{m}}$
B

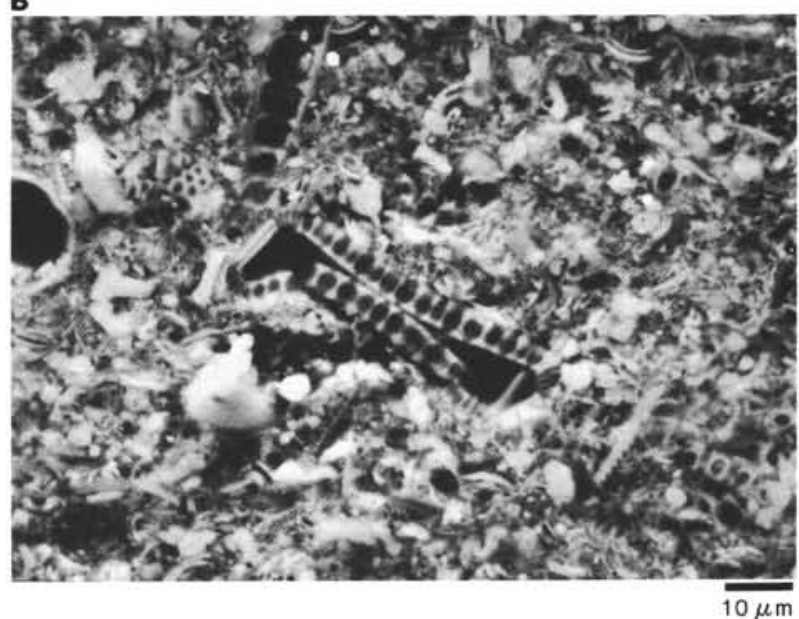

Figure 17. A. Sample 613-27-2, $68 \mathrm{~cm}(\sim 339 \mathrm{~m} \mathrm{SBD})$. Porosity $=49 \%, \mathrm{CaCO}_{3}=56 \%$. Unit II, middle Eocene, siliceous nannofossil chalk. Open foraminiferal tests with minor filling by sparry calcite. Scale bar $=100 \mu \mathrm{m}$. B. Sample $613-31-5,76 \mathrm{~cm}(\sim 381 \mathrm{~m} \mathrm{SBD})$. Porosity $=55 \%, \mathrm{CaCO}_{3}=46 \%$. Unit II, lower middle Eocene, siliceous nannofossil chalk. Compacted diatom test in matrix of biogenic fragments. Scale bar $=10 \mu \mathrm{m}$. C. Sample 613-37-5, $74 \mathrm{~cm}(\sim 437 \mathrm{~m} \mathrm{SBD})$. Porosity $=48 \%, \mathrm{CaCO}_{3}=34 \%$. Unit II, lower middle Eocene, siliceous nannofossil chalk. Significant volume of open tests present, but silica tests are beginning to degrade. Scale bar $=100 \mu \mathrm{m}$. Scanning electron microscope photomicrographs of backscattered electron images. Porosity and carbonate content values from samples adjacent to SEM samples. Unit designations and sediment type from core descriptions. 
A
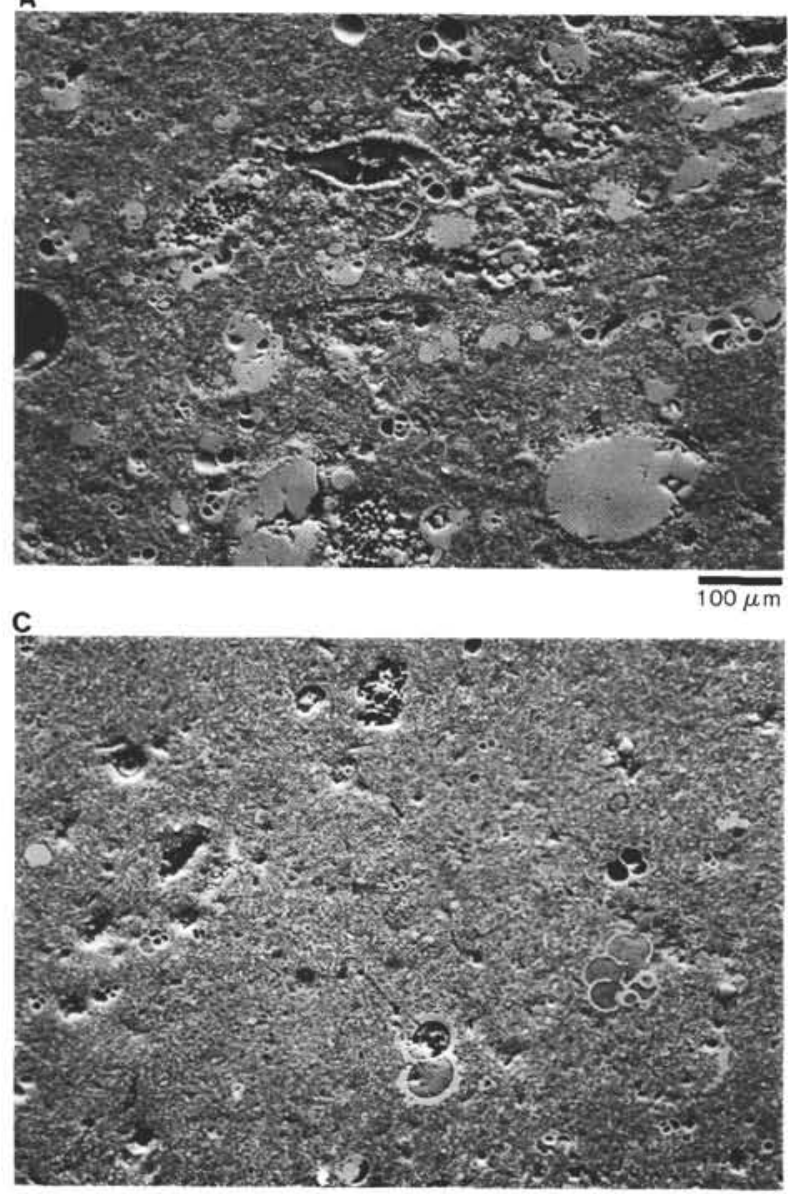

$\overline{100 \mu \mathrm{m}}$

$\mathbf{E}$

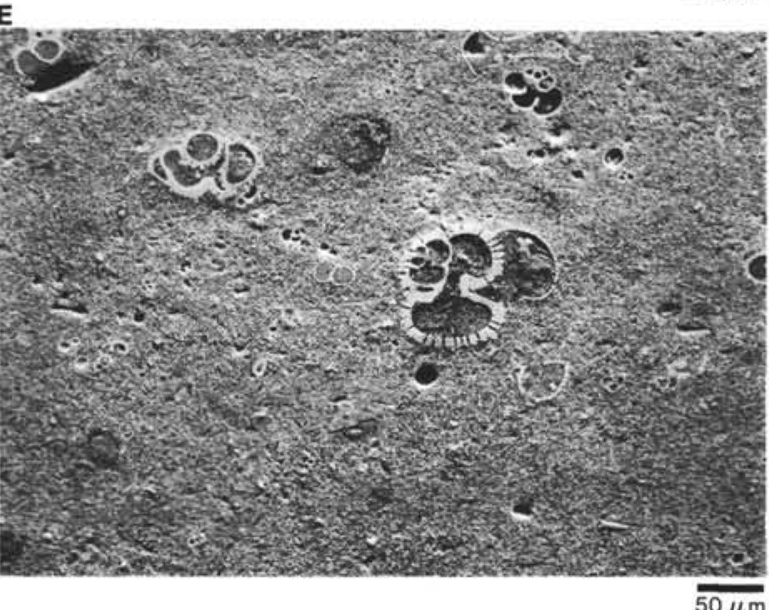

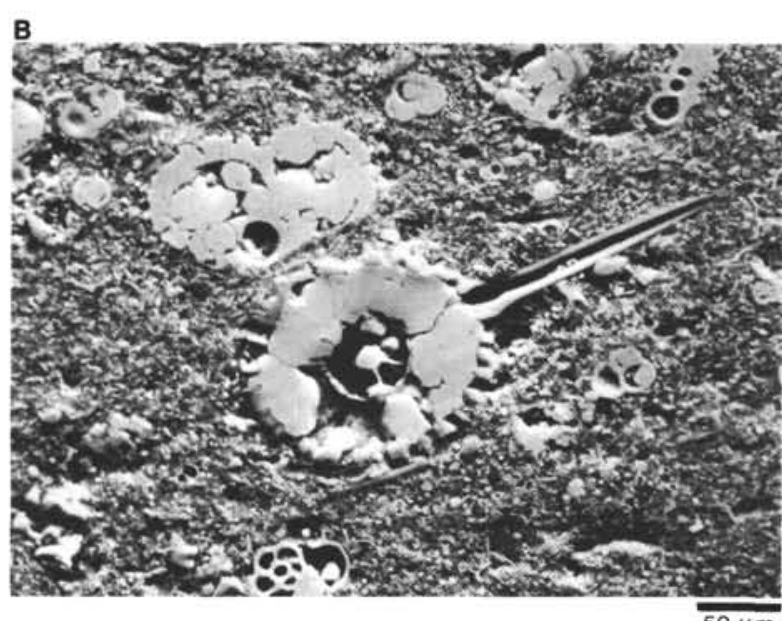

$50 \mu \mathrm{m}$

D

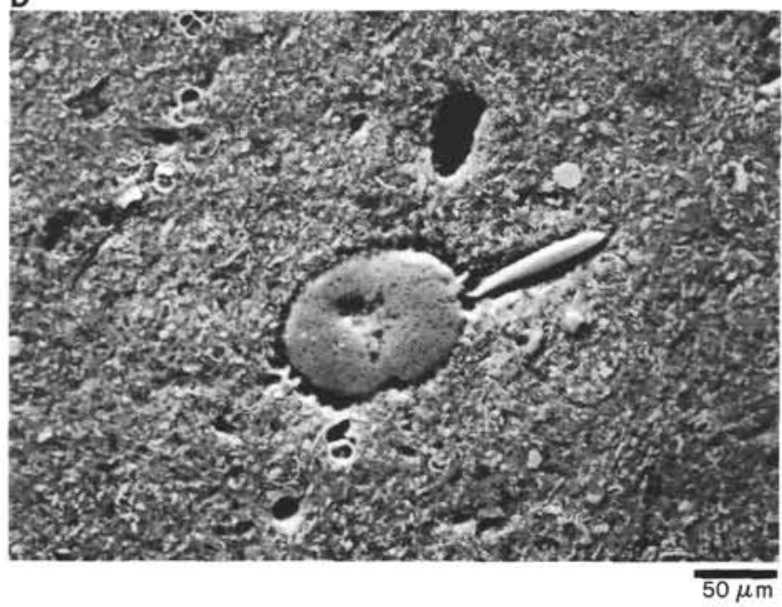

$\mathbf{F}$

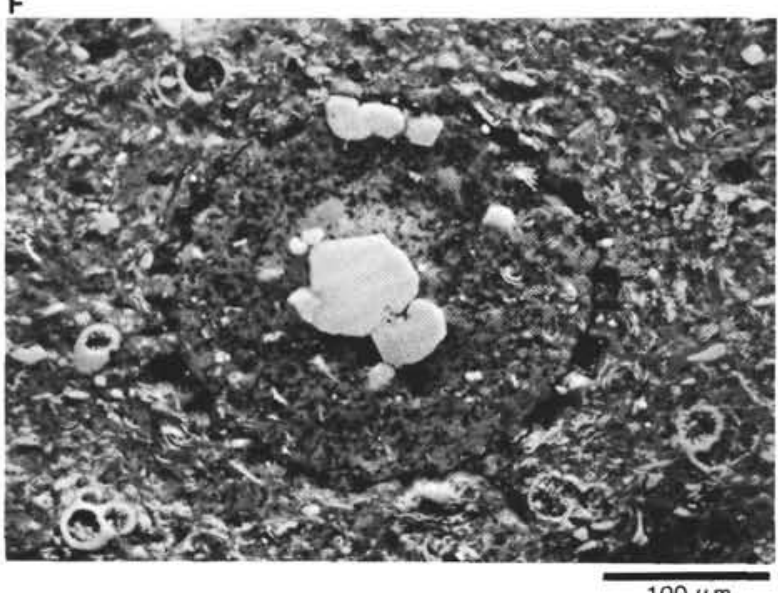

Figure 18. A. Sample 613-37-6, $73 \mathrm{~cm}(\sim 439 \mathrm{~m} \mathrm{SBD})$. Porosity $=38 \%, \mathrm{CaCO}_{3}=45 \%$. Unit III, middle-lower Eocene, slump deposit. Calcite infilling of radiolarian tests. Neither clinoptilolite or silica lepispheres are present. Scale bar $=100 \mu \mathrm{m}$. B. Same sample; calcified, calcite-infilled radiolarian test. Scale bar $=50 \mu \mathrm{m}$. C. Sample 613-38-4, $40 \mathrm{~cm}(\sim 445 \mathrm{~m} \mathrm{SBD})$. Porosity $=42 \%, \mathrm{CaCO}_{3}=34 \%$. Unit III, uppermost lower Eocene, porcellanitic limestone nodule in siliceous nannofossil chalk. Lepisphere and minor calcite filling of foraminifer tests. Scale bar $=100$ $\mu \mathrm{m}$. D. Same sample; Lepispheres filling mold of radiolarian test (compare with part B). Scale bar $=50 \mu \mathrm{m}$. E. Sample $613-39-5,75 \mathrm{~cm}(\sim 456$ $\mathrm{m} \mathrm{SBD}$ ). Porosity $=46 \%, \mathrm{CaCO}_{3}=40 \%$. Unit III, upper lower Eocene, porcellaneous nannofossil chalk. Lepispheres filling corroded foraminifer tests. Scale bar $=100 \mu \mathrm{m}$. F. Same sample; radiolarian mold filled with lepispheres and calcite. Small bright specks are barite. Scale bar $=$ $50 \mu \mathrm{m}$. Scanning electron microscope photomicrographs of backscattered electron images. Porosity and carbonate content values from samples adjacent to SEM samples. Unit designations and sediment type from core descriptions. 
A

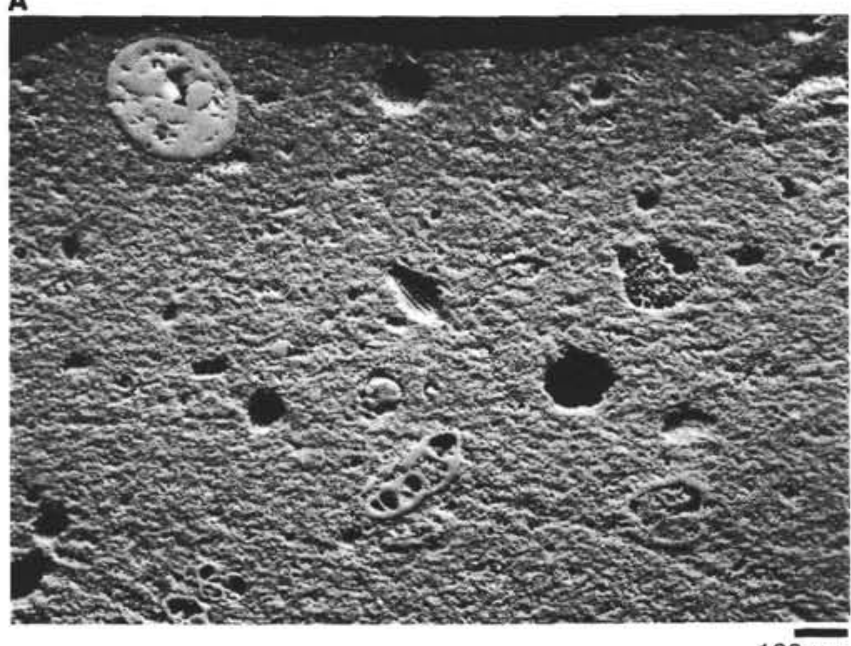

$100 \overline{\mu \mathrm{m}}$

B

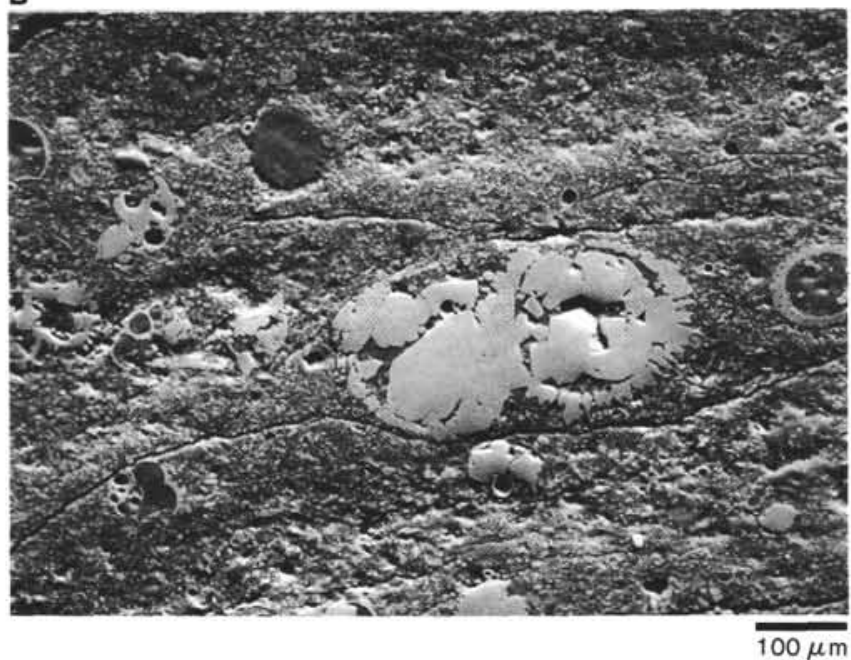

Figure 19. A. Sample 613-43-2, $47 \mathrm{~cm}(-489 \mathrm{~m} \mathrm{SBD})$. Porosity $=$ $40 \%, \mathrm{CaCO}_{3}=30 \%$. Unit II, upper lower Eocene, porcellaneous nannofossil limestone. Calcite and lepisphere filling of tests. Calcite has replaced some radiolarian tests. Scale bar $=100 \mu \mathrm{m}$. B Sample 613-50-1, $71 \mathrm{~cm}(\sim 554 \mathrm{~m} \mathrm{SBD})$. Porosity $=43 \%, \mathrm{CaCO}_{3}$ $=39 \%$. Unit III, middle lower Eocene, nannofossil chalk. Foraminifer tests infilled with calcite and lepispheres. Note that there is no evidence for growth of calcite surrounding lepispheres (compare to Sample 612-50-2, $71 \mathrm{~cm}$, Fig. 15D, E). Scale bar $=100 \mu \mathrm{m}$. Scanning electron microscope photomicrographs of backscattered electron images. Porosity and carbonate content values from samples adjacent to SEM samples. Unit designations and sediment type from core descriptions. 